\title{
From Hydrate to Peroxosolvate: A Test of Prediction with Cyclic N-oxides
}

\author{
Supporting Information \\ Leila M. Foroughi and Adam J. Matzger* \\ Department of Chemistry, Macromolecular Science and Engineering Program, University of Michigan, 930 North \\ University Avenue, Ann Arbor, Michigan 48109-1055, United States
}

\section{Table of Contents}

S1. Cambridge Structural Database (CSD) Search

S2. Crystallization Conditions

S3. Raman Spectroscopy

S4. Table of Crystallographic data

S5. ORTEP Diagrams

S6. Crystal Morphology 


\section{S1. CSD Search Results}

Table S1. All 71 entries generated from the Cambridge Structural Database. ${ }^{1}$ Entries that were repeats of the same compound, had more than two species, or did not contain $N$-oxide groups were eliminated. The commercial availability of compounds was determined using Scifinder, and chemicals that were available from major chemical suppliers were purchased.

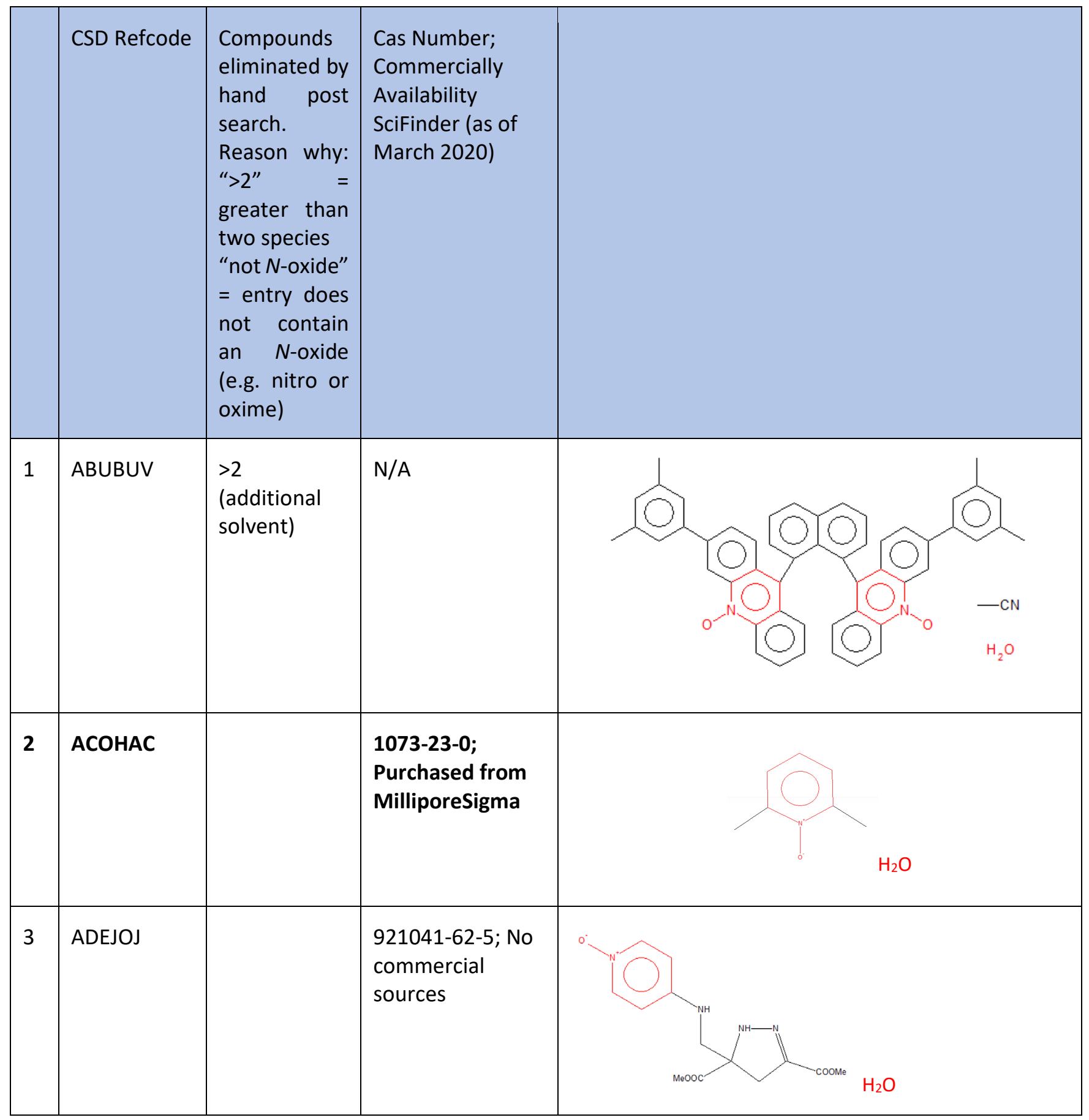




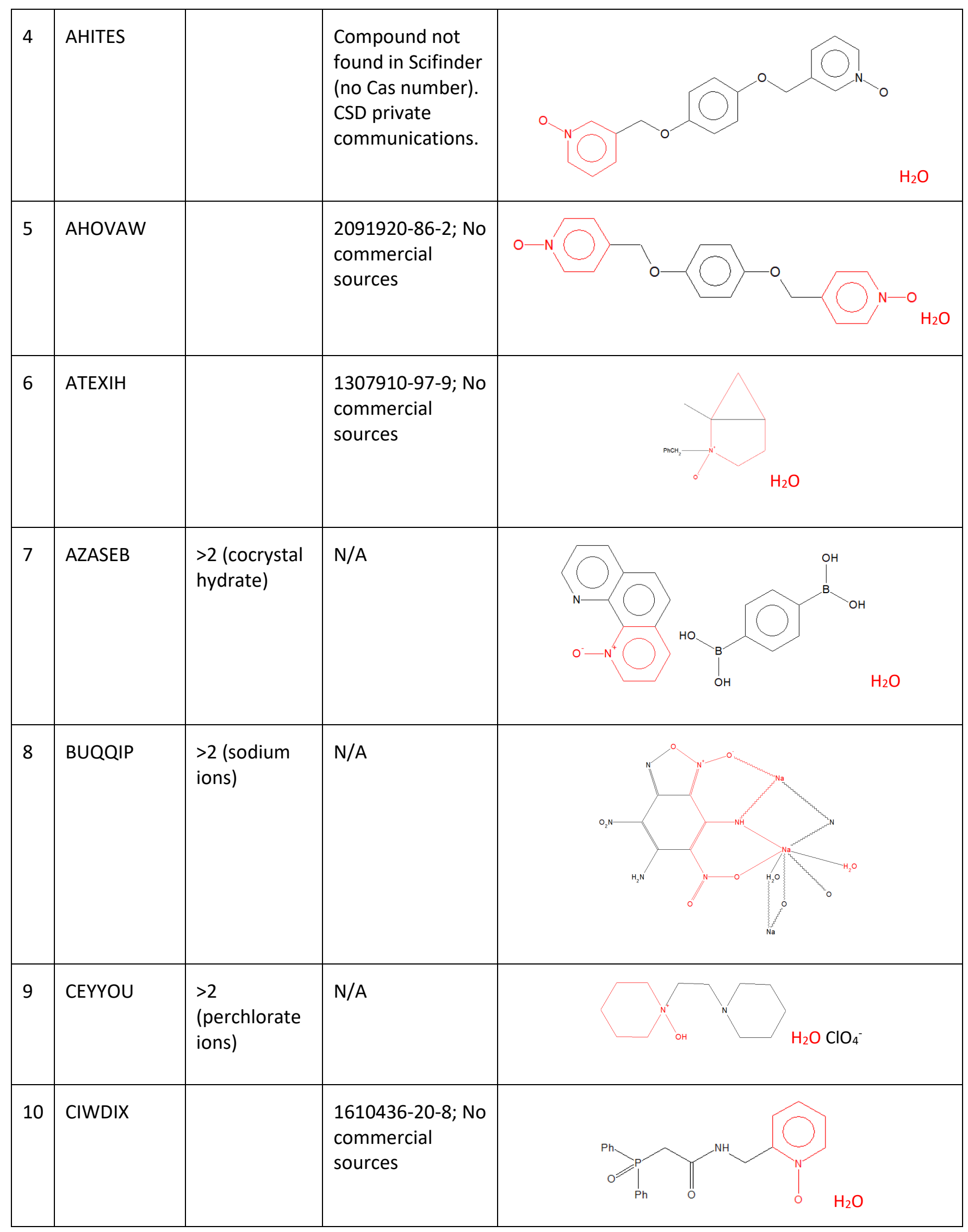




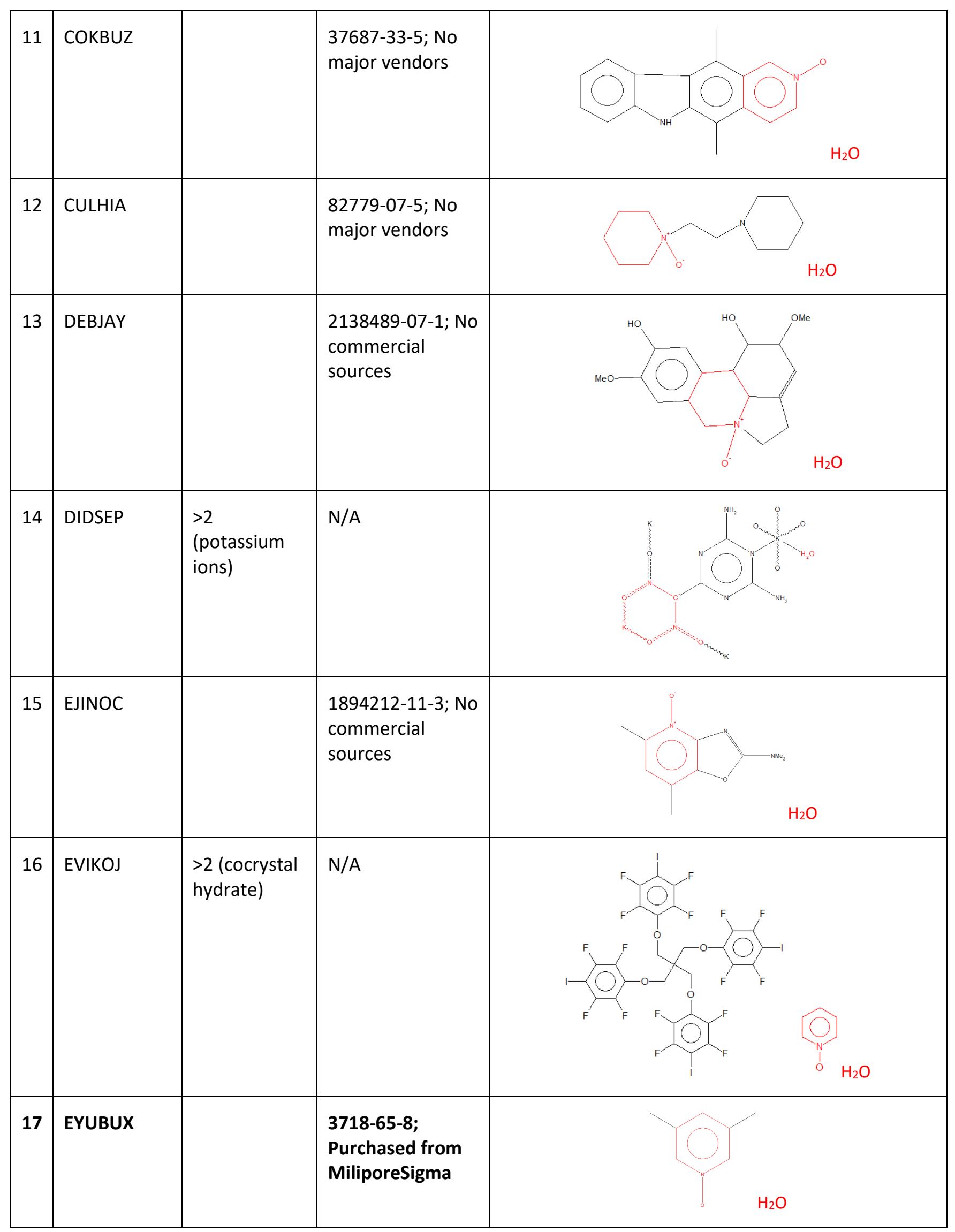




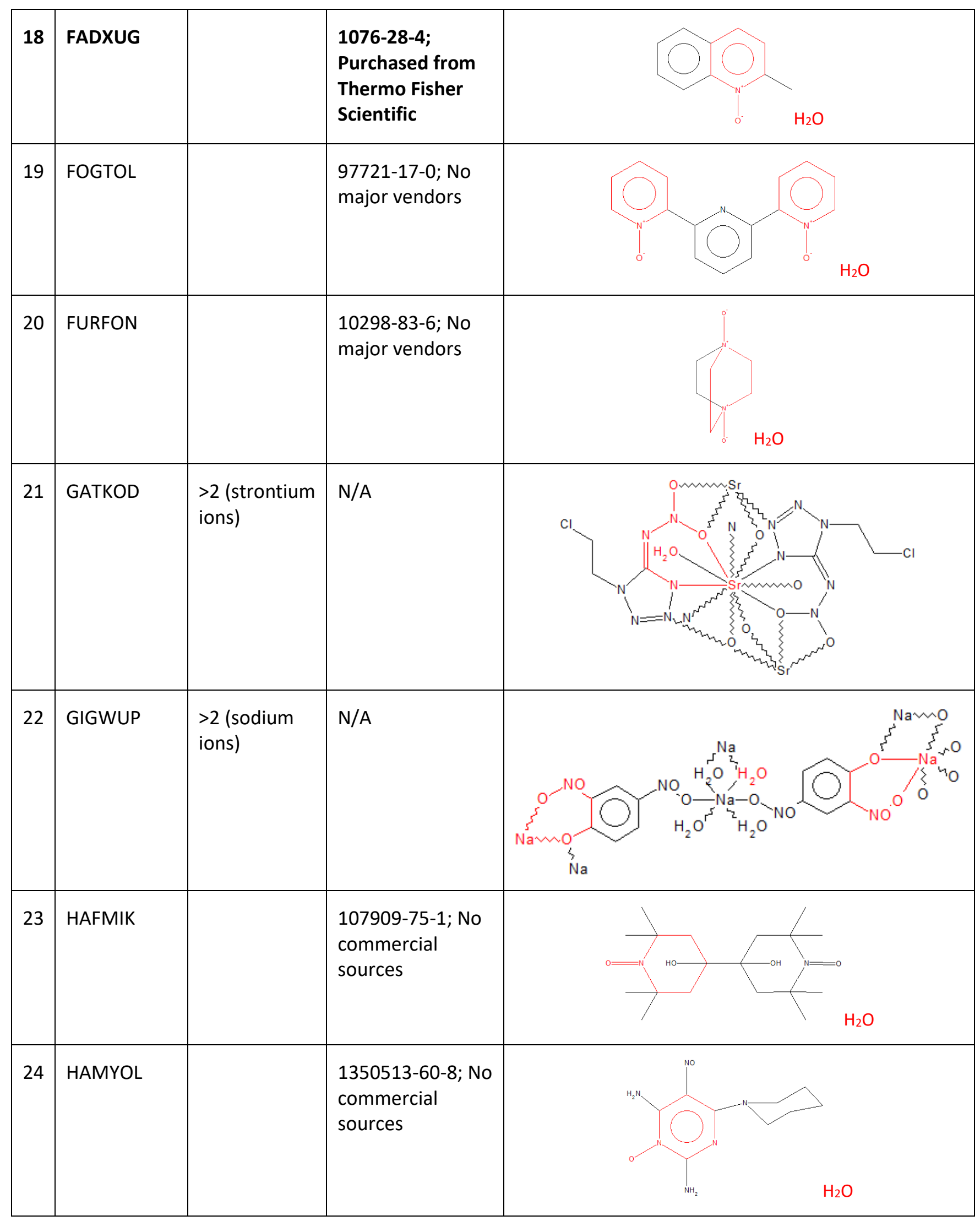




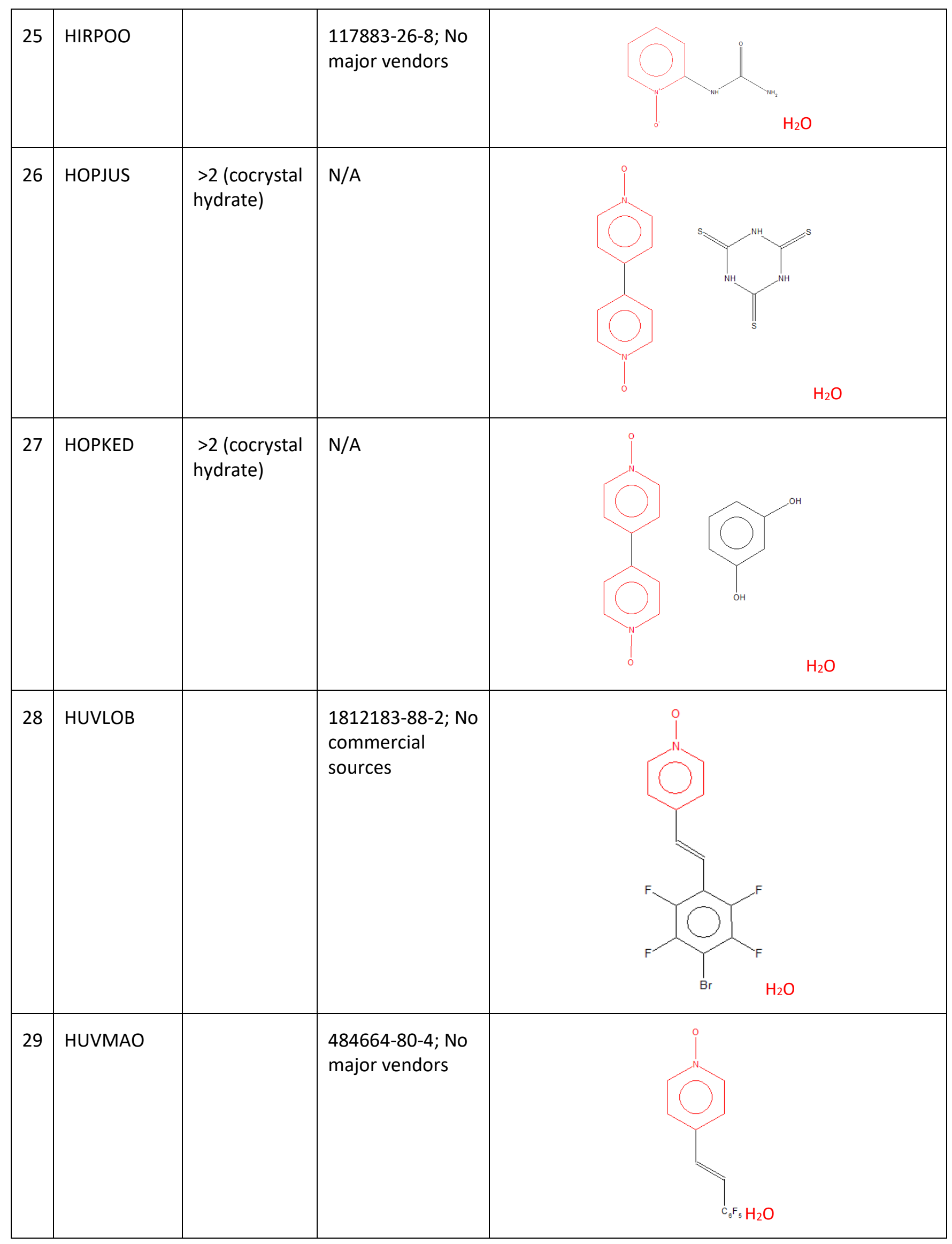




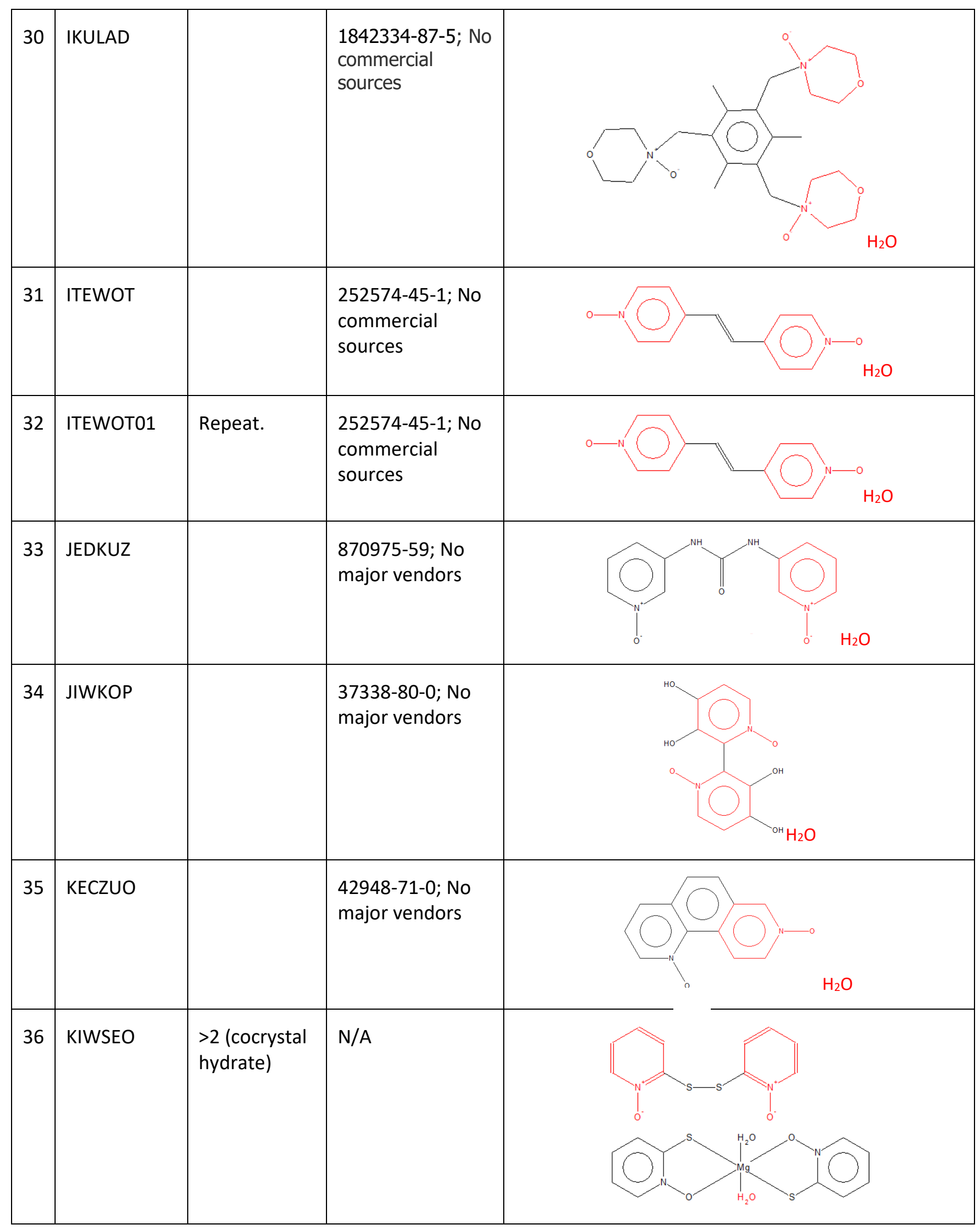




\begin{tabular}{|c|c|c|c|c|}
\hline 37 & KOMQEJ & $\begin{array}{l}>2 \\
\text { (additional } \\
\text { solvent) }\end{array}$ & N/A & 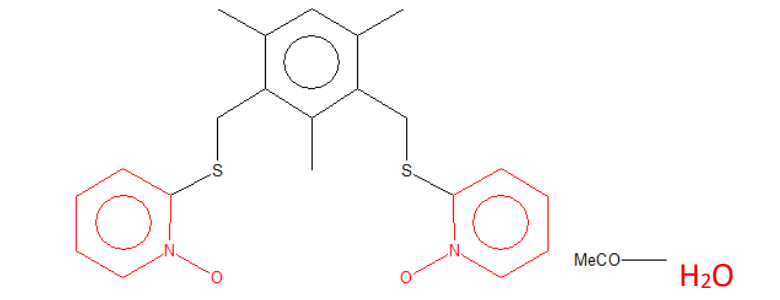 \\
\hline 38 & KUSYAZ & & $\begin{array}{l}\text { 14631-48-2; } \\
\text { Purchased from } \\
\text { MilliporeSigma; }\end{array}$ & \\
\hline 39 & LOYYOP & $\begin{array}{l}>2 \text { (cocrystal } \\
\text { hydrate) }\end{array}$ & N/A & \\
\hline 40 & MEGCUX & $\begin{array}{l}>2 \text { (cocrystal } \\
\text { hydrate) }\end{array}$ & N/A & \\
\hline 41 & MEJXOR & & $\begin{array}{l}\text { Compound not } \\
\text { found in Scifinder } \\
\text { (no Cas number). } \\
\text { CSD private } \\
\text { communications }\end{array}$ & \\
\hline 42 & NAJDAF & & $\begin{array}{l}1210358-50-1 ; \text { No } \\
\text { commercial } \\
\text { sources }\end{array}$ & \\
\hline 43 & NELYIN & & $\begin{array}{l}312300-91-7 ; \text { No } \\
\text { commercial } \\
\text { sources }\end{array}$ & 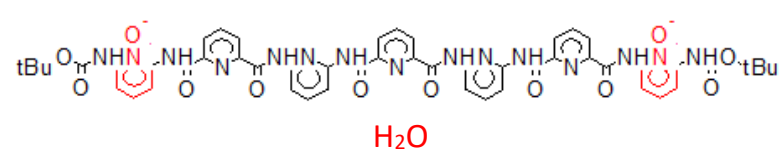 \\
\hline 44 & NELYOT & $\begin{array}{l}>2 \\
\text { (additional } \\
\text { solvent) }\end{array}$ & $\mathrm{N} / \mathrm{A}$ & 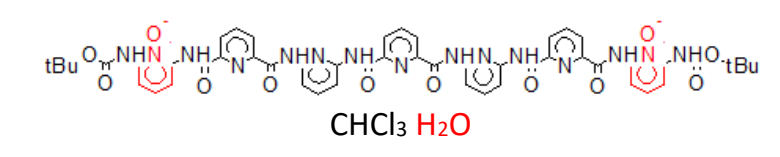 \\
\hline 45 & NELYUZ & $\begin{array}{l}>2 \\
\text { (additional } \\
\text { solvent) }\end{array}$ & N/A & 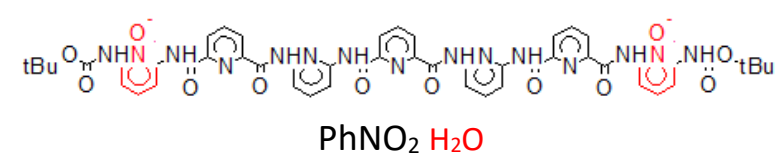 \\
\hline
\end{tabular}




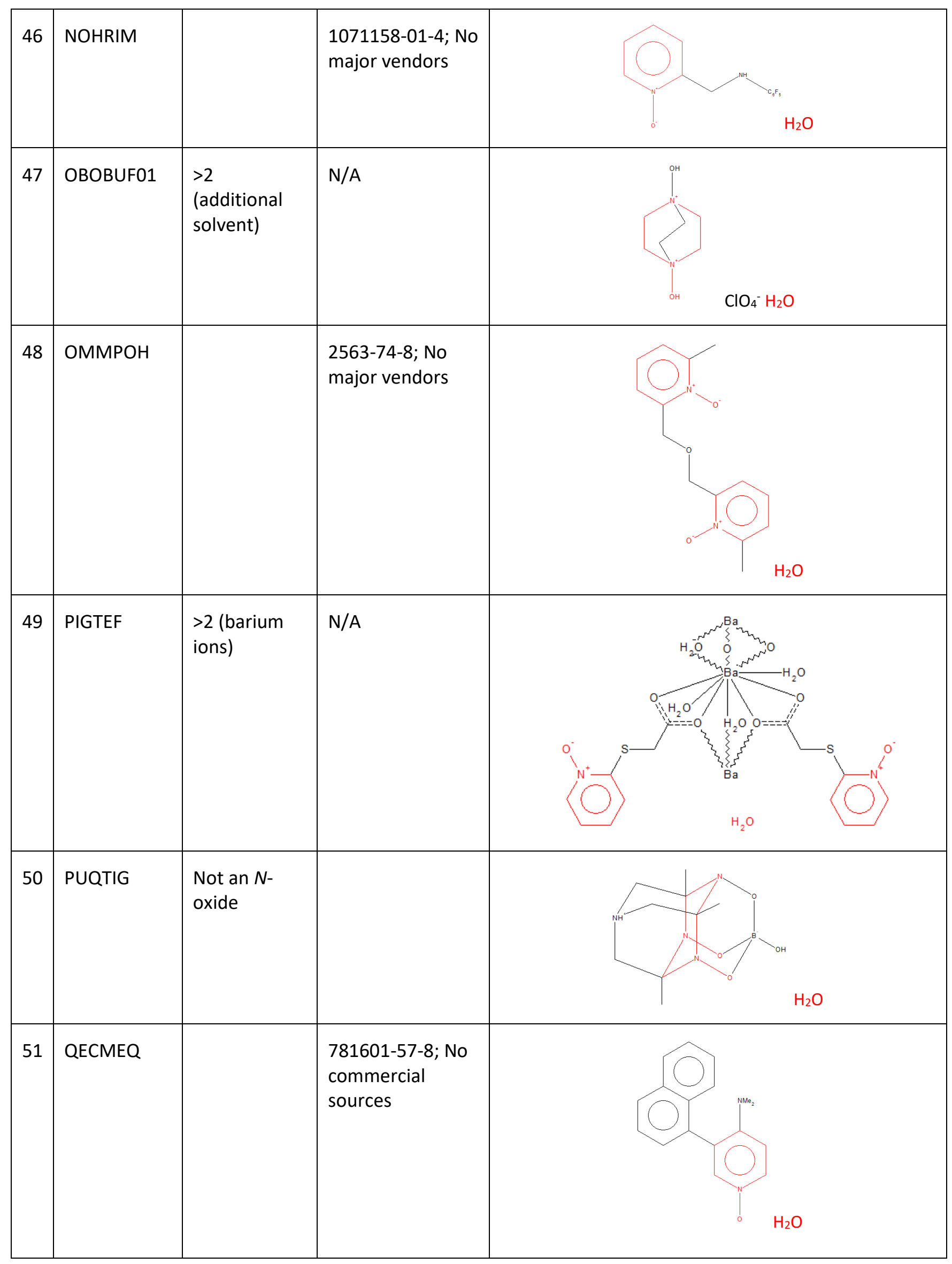




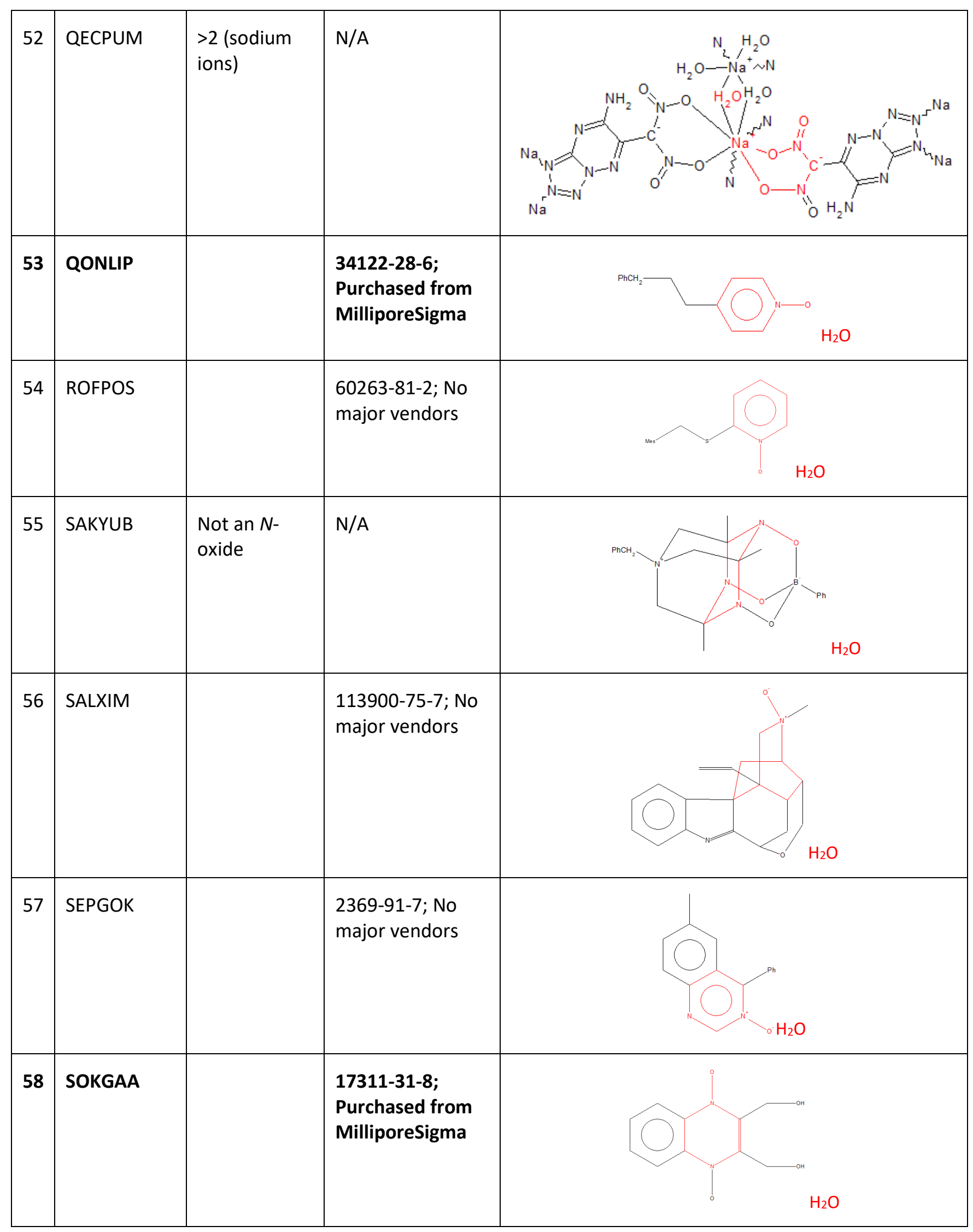




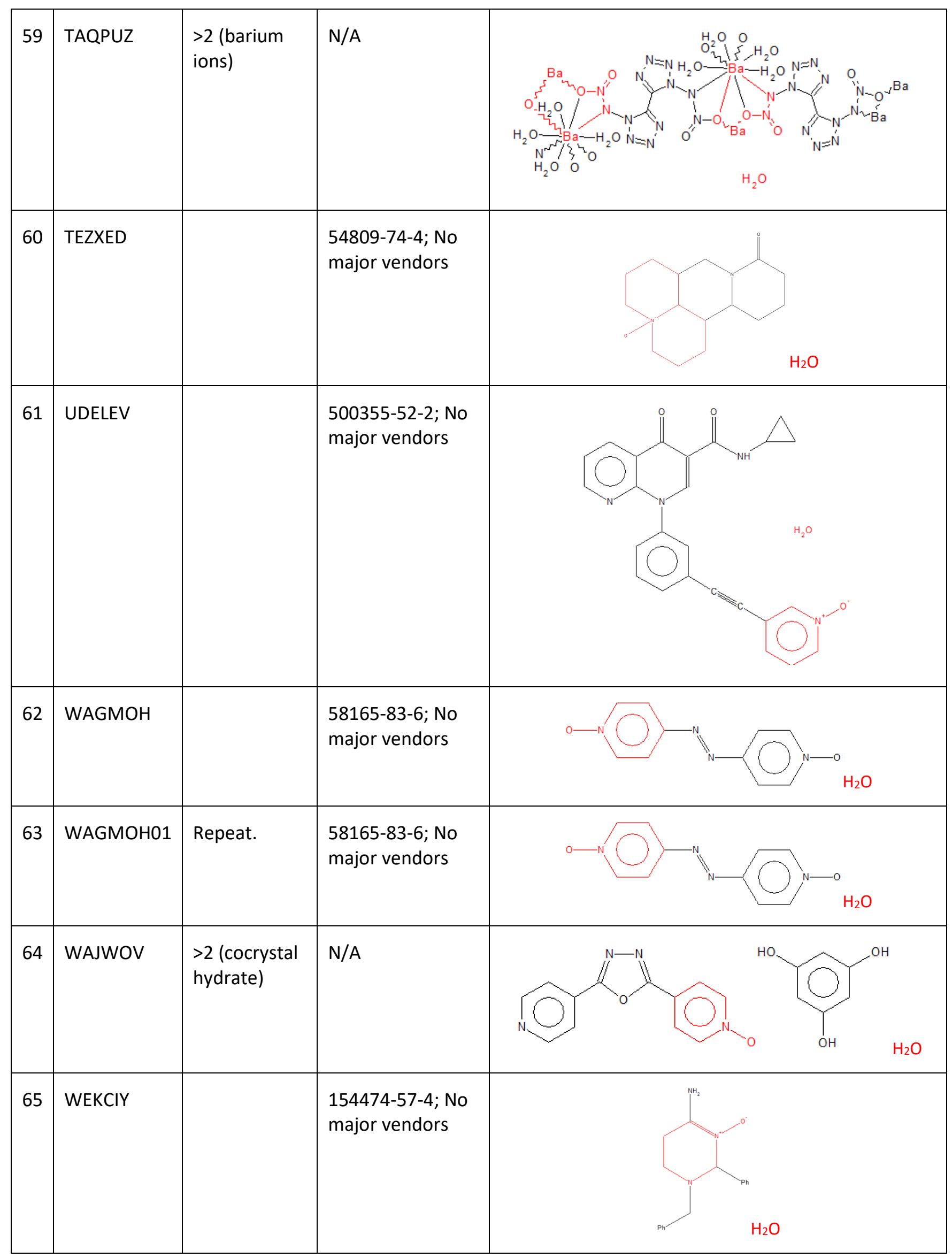




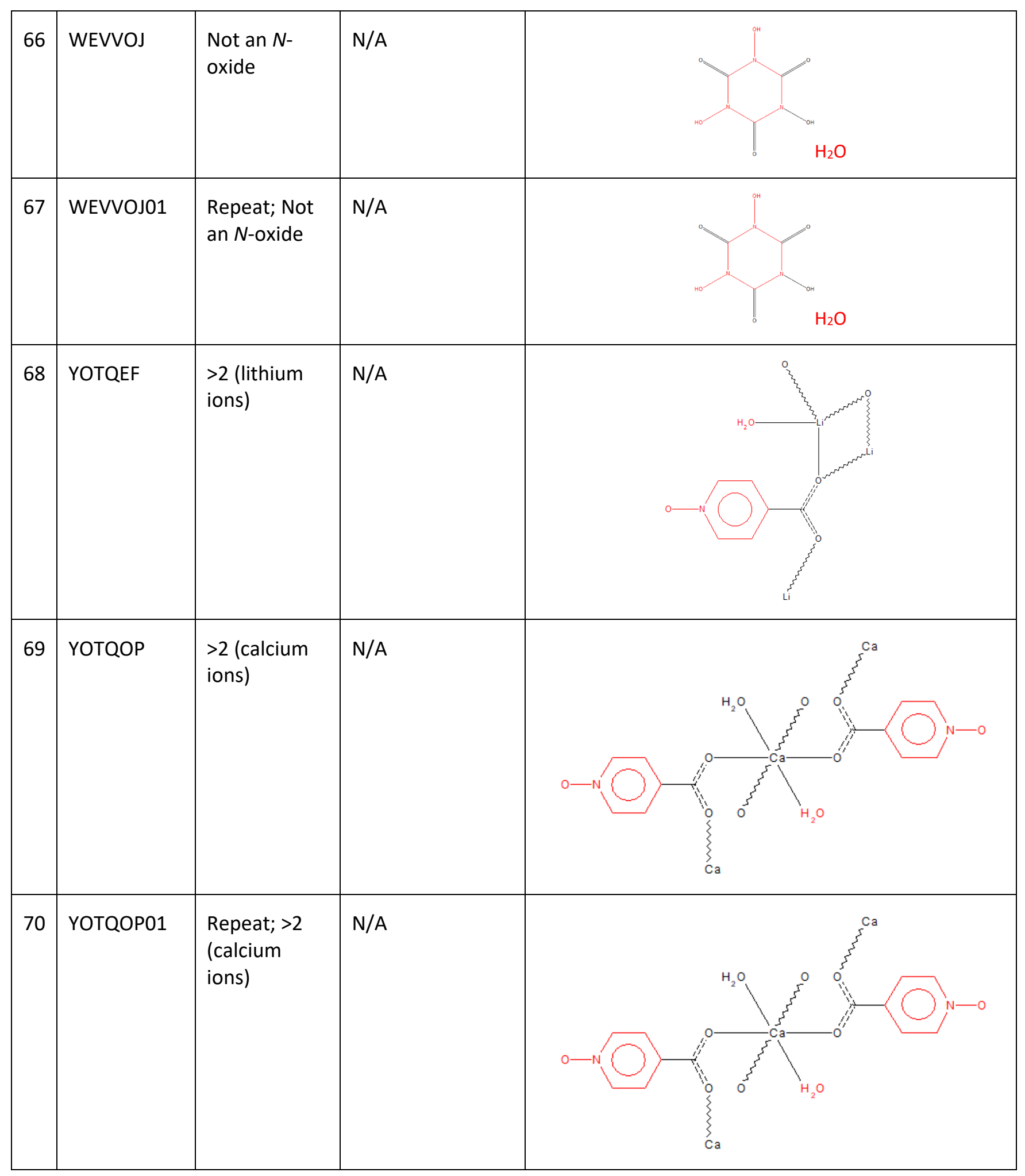




\begin{tabular}{|l|l|l|l|l|}
\hline YUTSOX & $\begin{array}{l}\text { ladditional } \\
\text { solvent) }\end{array}$
\end{tabular}

\section{S2. Crystallization Conditions}

Conditions used to obtain the crystals characterized using Raman spectroscopy and X-ray crystallography

Table S2. Slurry crystallization conditions for $\mathbf{1}$ and 3-6.

\begin{tabular}{|c|c|}
\hline \multicolumn{2}{|c|}{ Compound Crystallization condition } \\
\hline $1-\mathrm{H}_{2} \mathrm{O}_{2}$ & $50 / 50$ by volume ethyl acetate/ $98 \%$ hydrogen peroxide \\
\hline $3-\mathrm{H}_{2} \mathrm{O}_{2}$ & 98\% hydrogen peroxide \\
\hline $4-\mathrm{H}_{2} \mathrm{O}_{2}$ & $50 / 50$ by volume acetonitrile/ $98 \%$ hydrogen peroxide \\
\hline $5-\mathrm{H}_{2} \mathrm{O}_{2}$ & $50 / 50$ by volume dichloromethane/98\% hydrogen peroxide \\
\hline $6-\mathrm{H}_{2} \mathrm{O}_{2}$ & $50 / 50$ by volume acetonitrile/ $98 \%$ hydrogen peroxide \\
\hline
\end{tabular}

\section{S3. Raman Spectroscopy}

\section{Raman Spectra of 1}

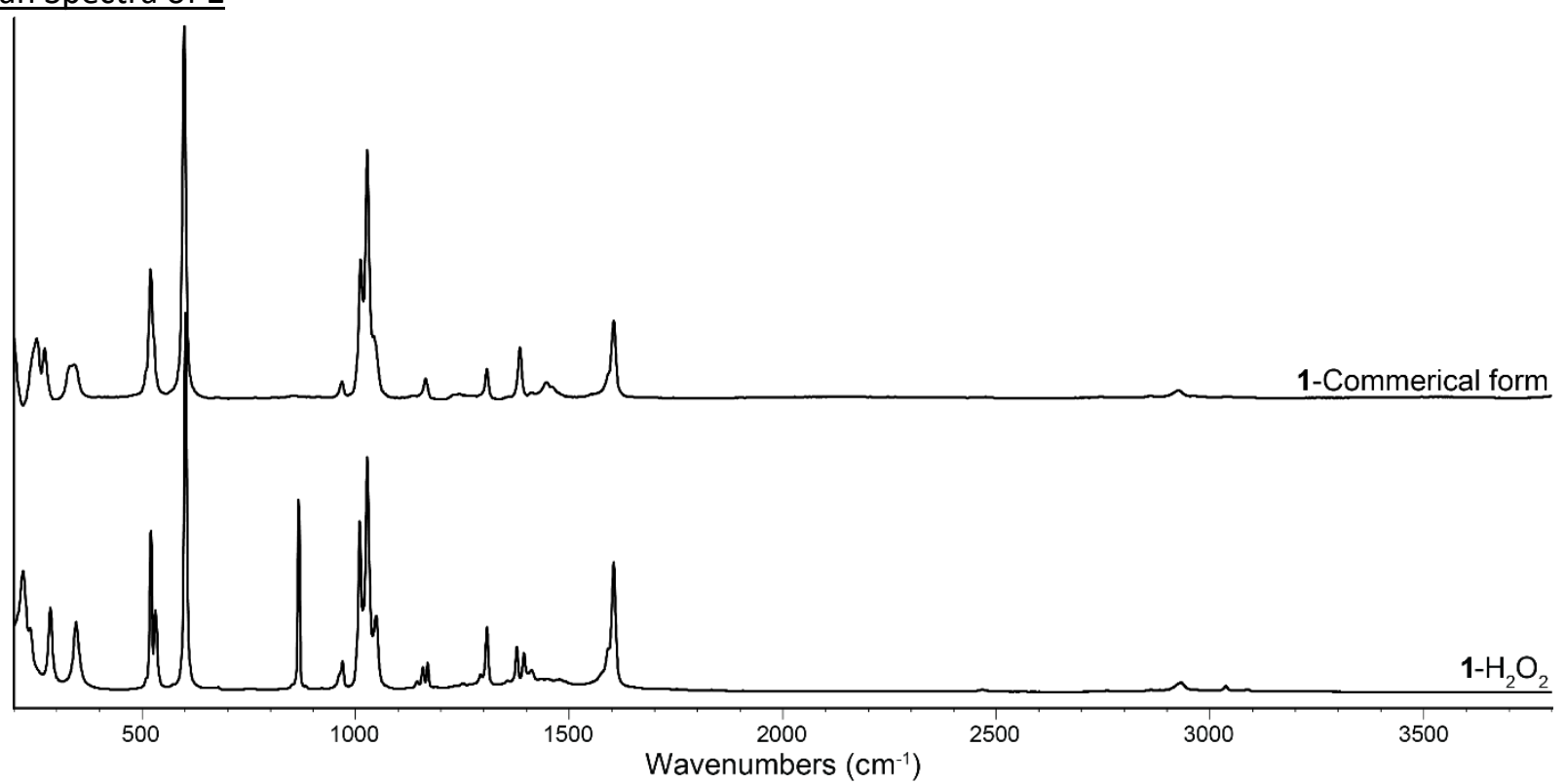

Figure S1. Full Range $\left(200-3800 \mathrm{~cm}^{-1}\right)$. Raman spectra of the commercial form (top) and peroxosolvate (bottom) of 1. 


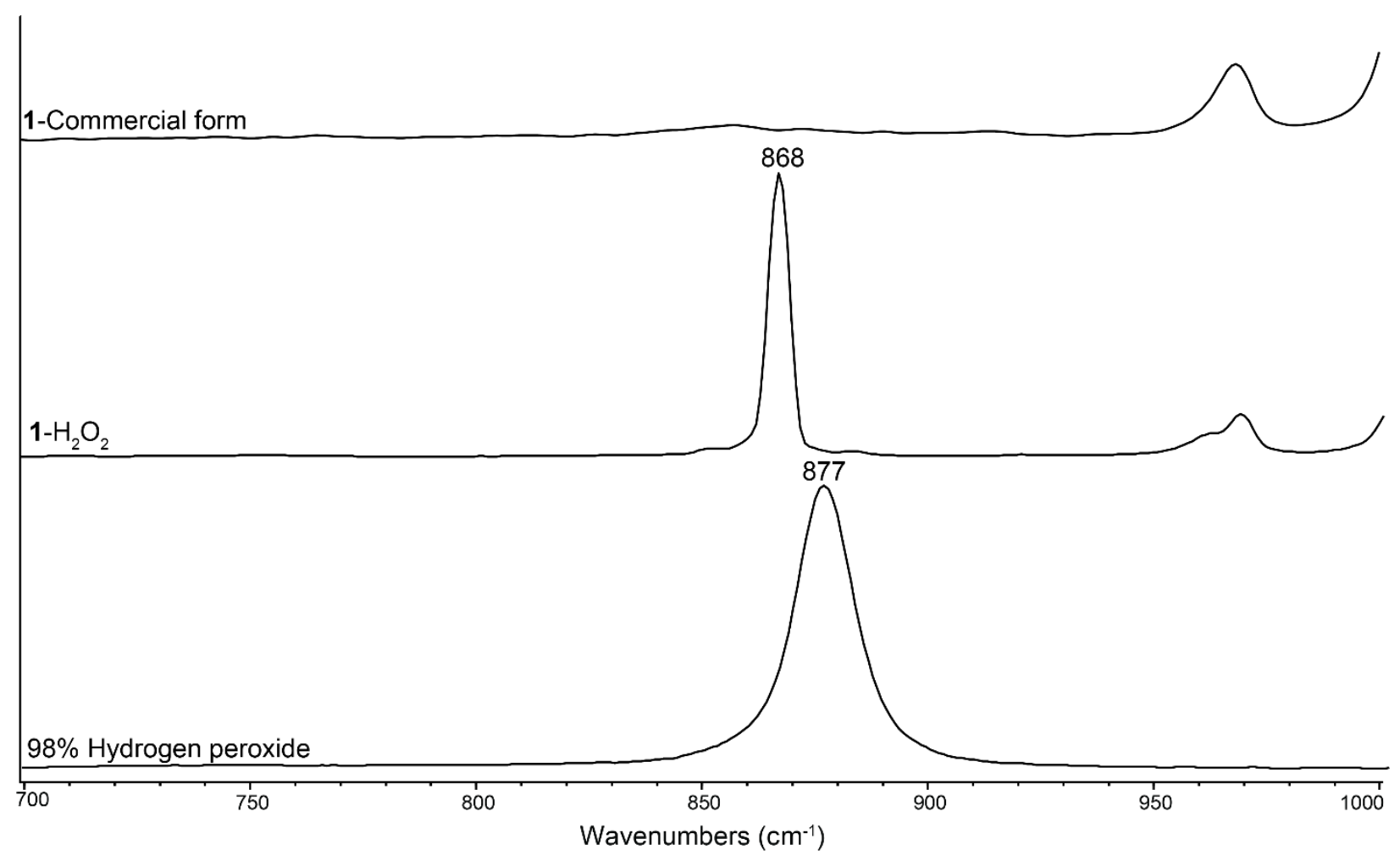

Figure S2. Zoomed in (700-1000 $\left.\mathrm{cm}^{-1}\right)$. Raman spectra of the commercial form of $\mathbf{1}$ (top), the peroxosolvate of 1 (middle), and $98 \%$ hydrogen peroxide (bottom) in the region where the hydrogen peroxide O-O stretch can be observed.

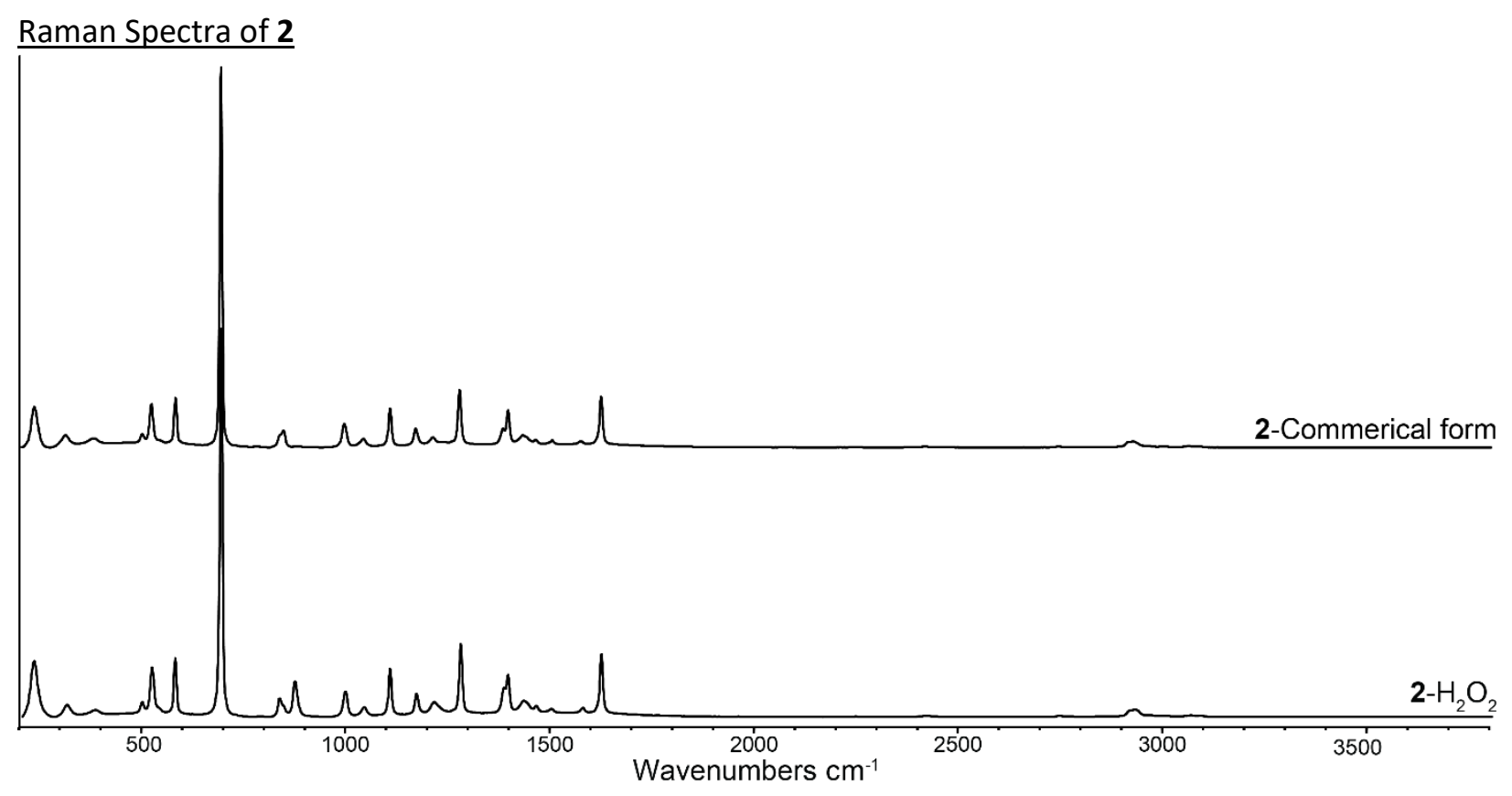

Figure S3. Full Range $\left(200-3800 \mathrm{~cm}^{-1}\right)$. Raman spectra of the commercial form (top) and peroxosolvate (bottom) of 2. 


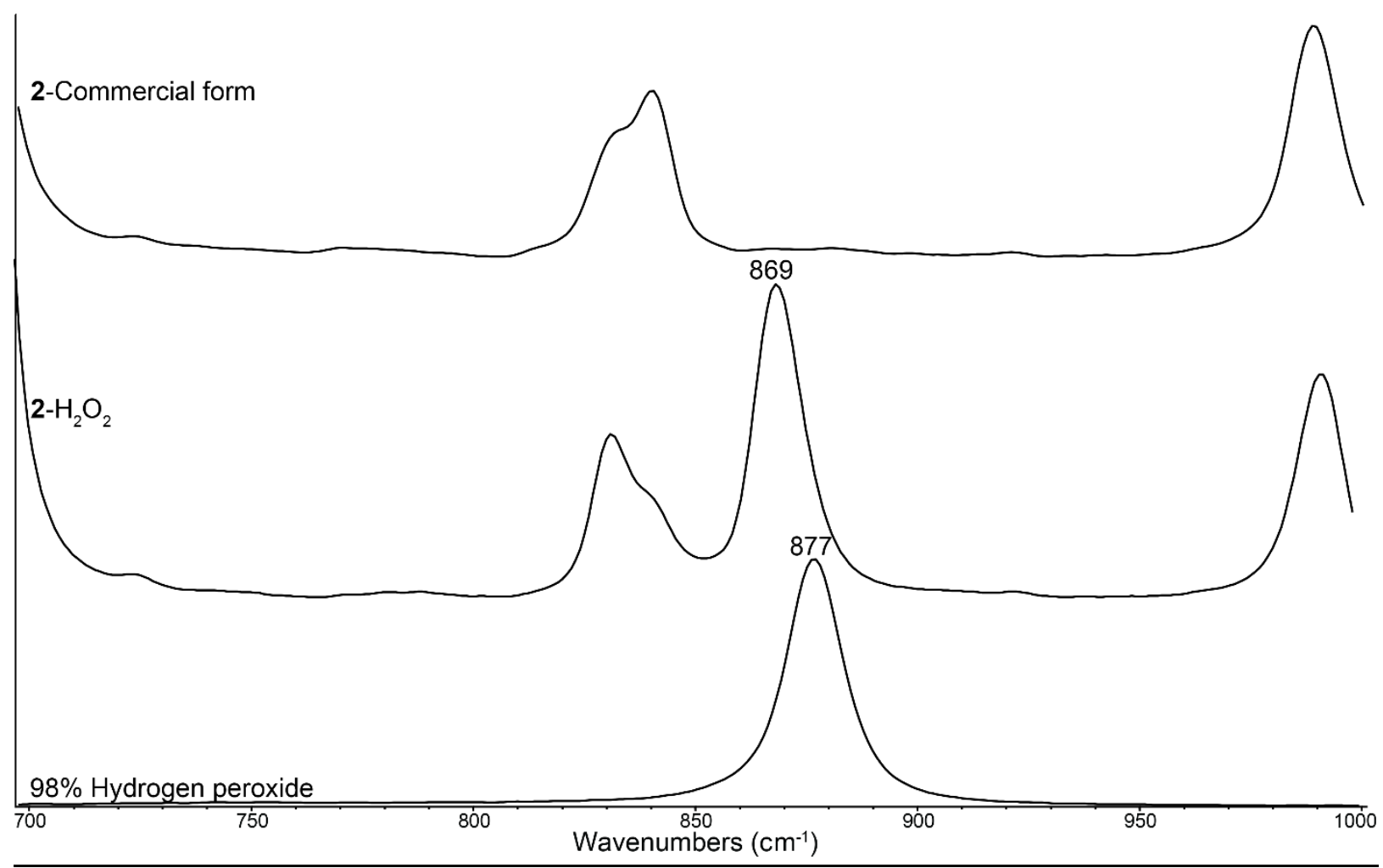

Figure S4. Zoomed in (700-1000 $\left.\mathrm{cm}^{-1}\right)$. Raman spectra of the commercial form of $\mathbf{2}$ (top), the peroxosolvate of $\mathbf{2}$ (middle), and $98 \%$ hydrogen peroxide (bottom) in the region where the hydrogen peroxide $\mathrm{O}-\mathrm{O}$ stretch can be observed.

\section{$\underline{\text { Raman Spectra of } \mathbf{3}}$}

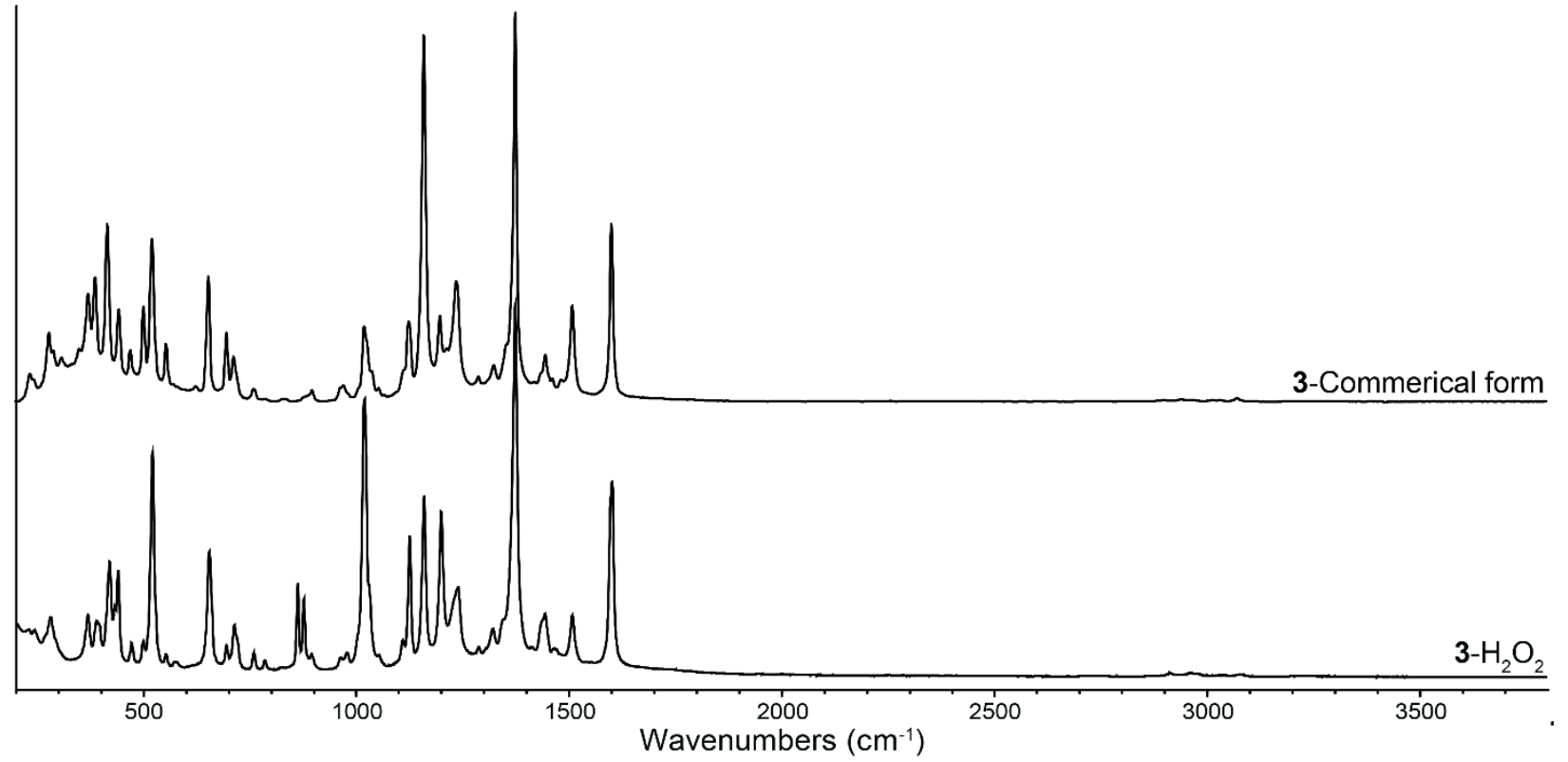

Figure S5. Full Range (200-3800 $\left.\mathrm{cm}^{-1}\right)$. Raman spectra of the commercial form (top) and peroxosolvate (bottom) of 3. 


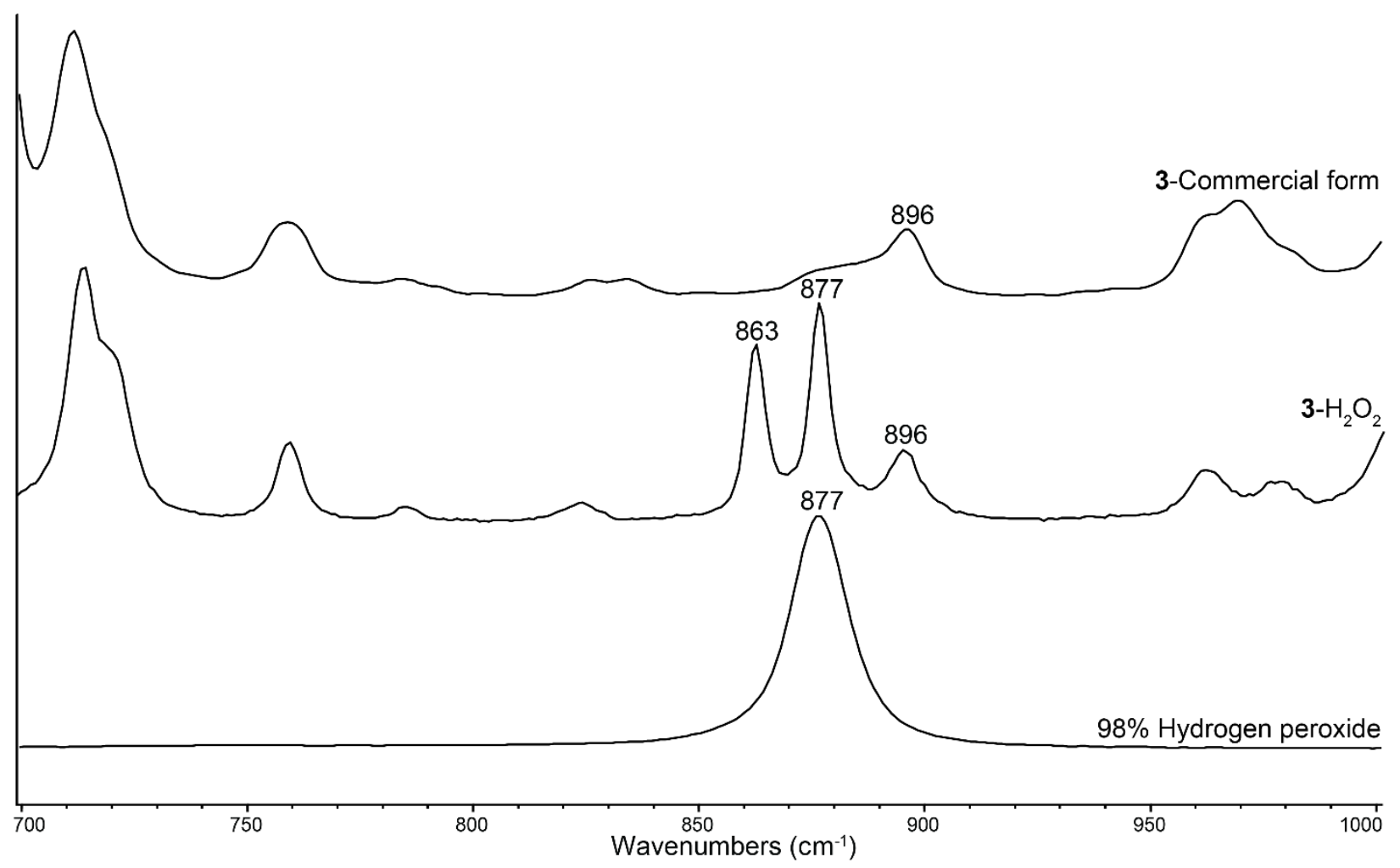

Figure S6. ${ }^{*}$ Zoomed in (700-1000 $\left.\mathrm{cm}^{-1}\right)$ Raman spectra of the commercial form of $\mathbf{3}$ (top), the peroxosolvate of $\mathbf{3}$ (middle), and $98 \%$ hydrogen peroxide (bottom) in the region where the hydrogen peroxide $0-0$ stretch can be observed. Two peaks are observed in the peroxosolvate, that are not observed in the commercial form, a peak at 862 and $877 \mathrm{~cm}^{-1}$. The peak at $877 \mathrm{~cm}^{-1}$ overlaps with free peroxide, but is observed after washing and air drying $3-\mathrm{H}_{2} \mathrm{O}_{2}$ crystals and is much sharper than peroxide liquid.

\section{Raman Spectra of 4}

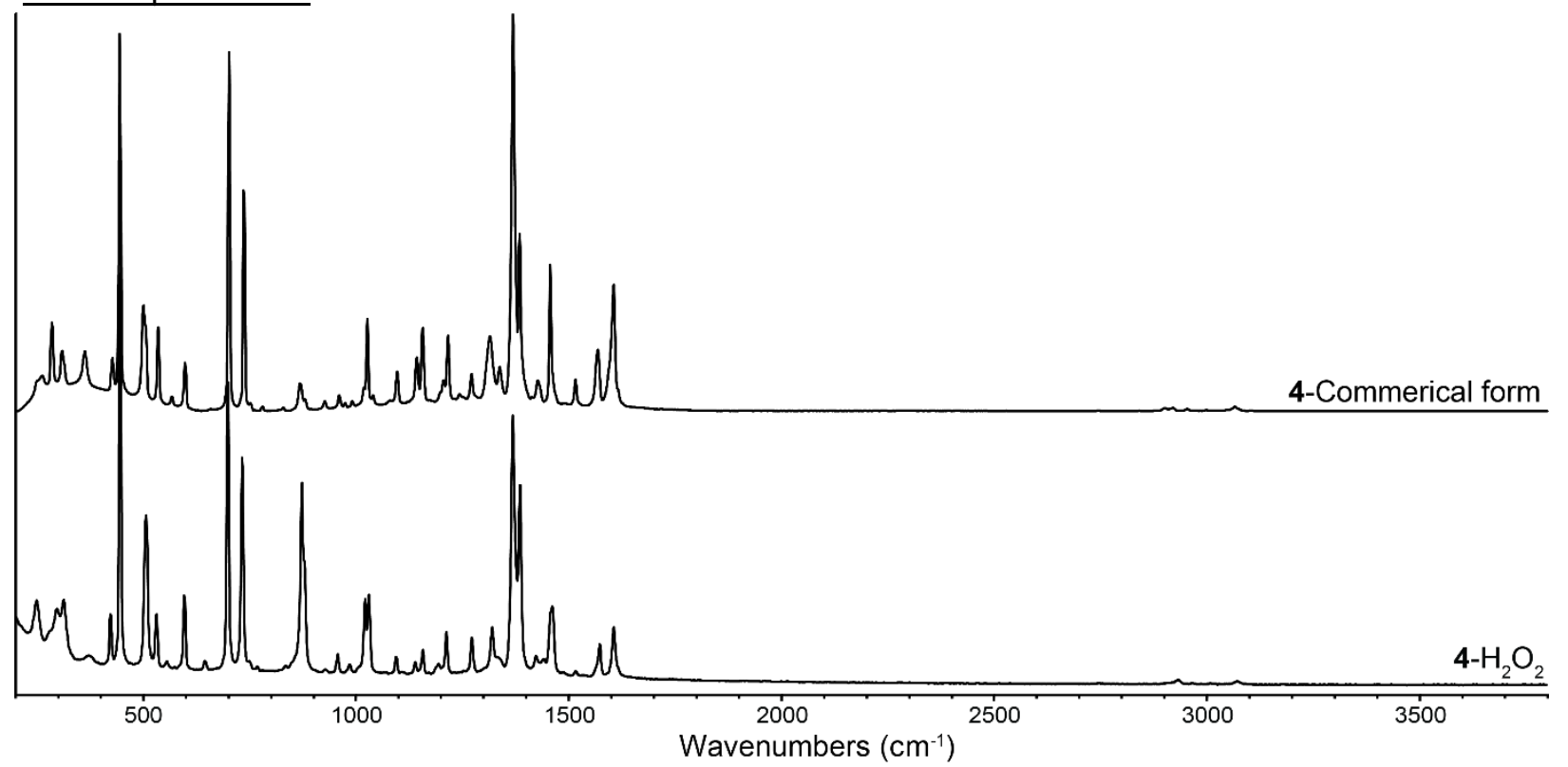

Figure S7. Full Range $\left(200-3800 \mathrm{~cm}^{-1}\right)$. Raman spectra of the commercial form (top) and peroxosolvate (bottom) of 4. 


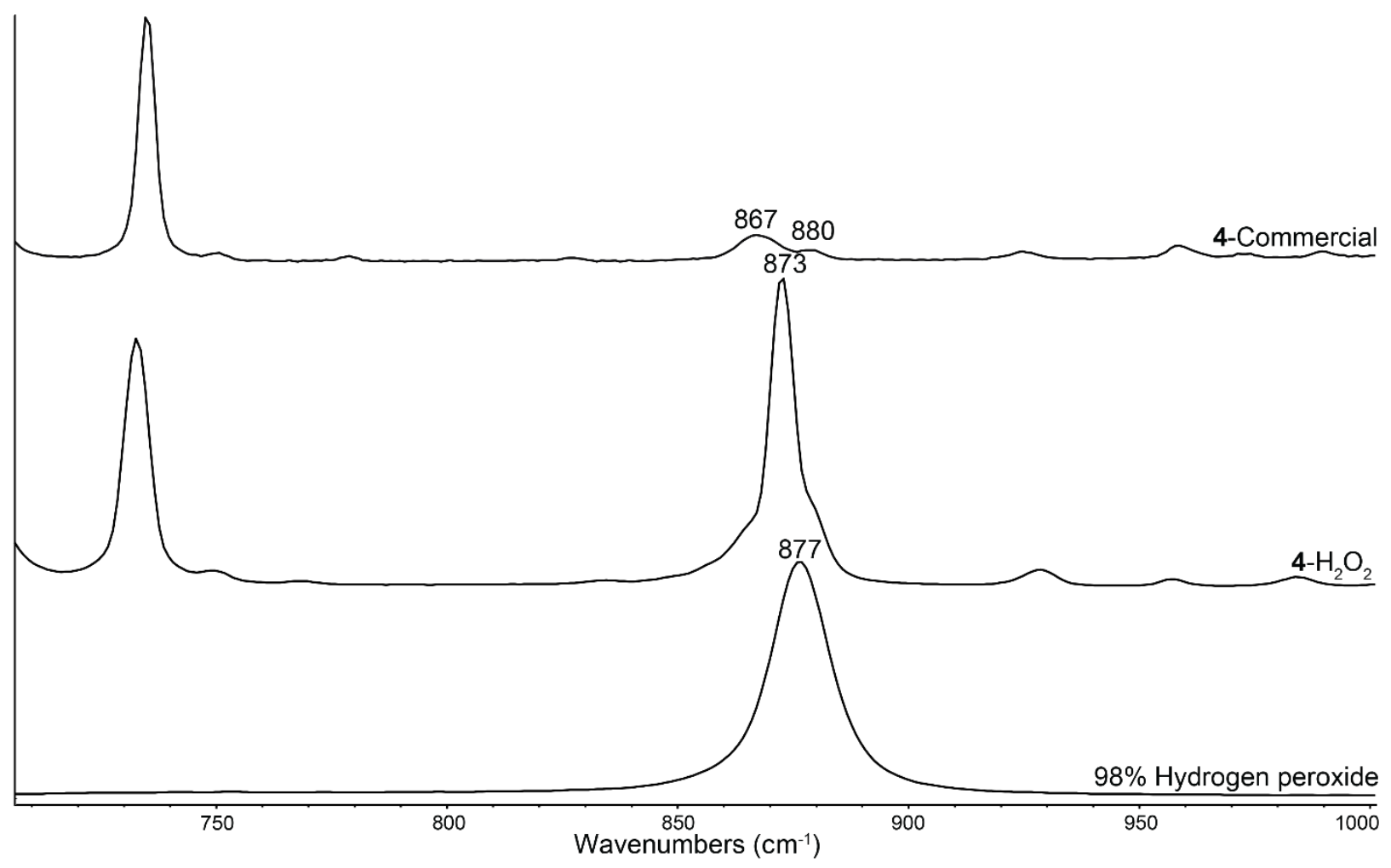

Figure S8. ${ }^{*}$ Zoomed in (700-1000 $\left.\mathrm{cm}^{-1}\right)$. Raman spectra of the commercial form of 4 (top), the peroxosolvate of 4 (middle), and $98 \%$ hydrogen peroxide (bottom) in the region where the hydrogen peroxide $\mathrm{O}-\mathrm{O}$ stretch can be observed.

\section{$\underline{\text { Raman Spectra of } \mathbf{5}}$}

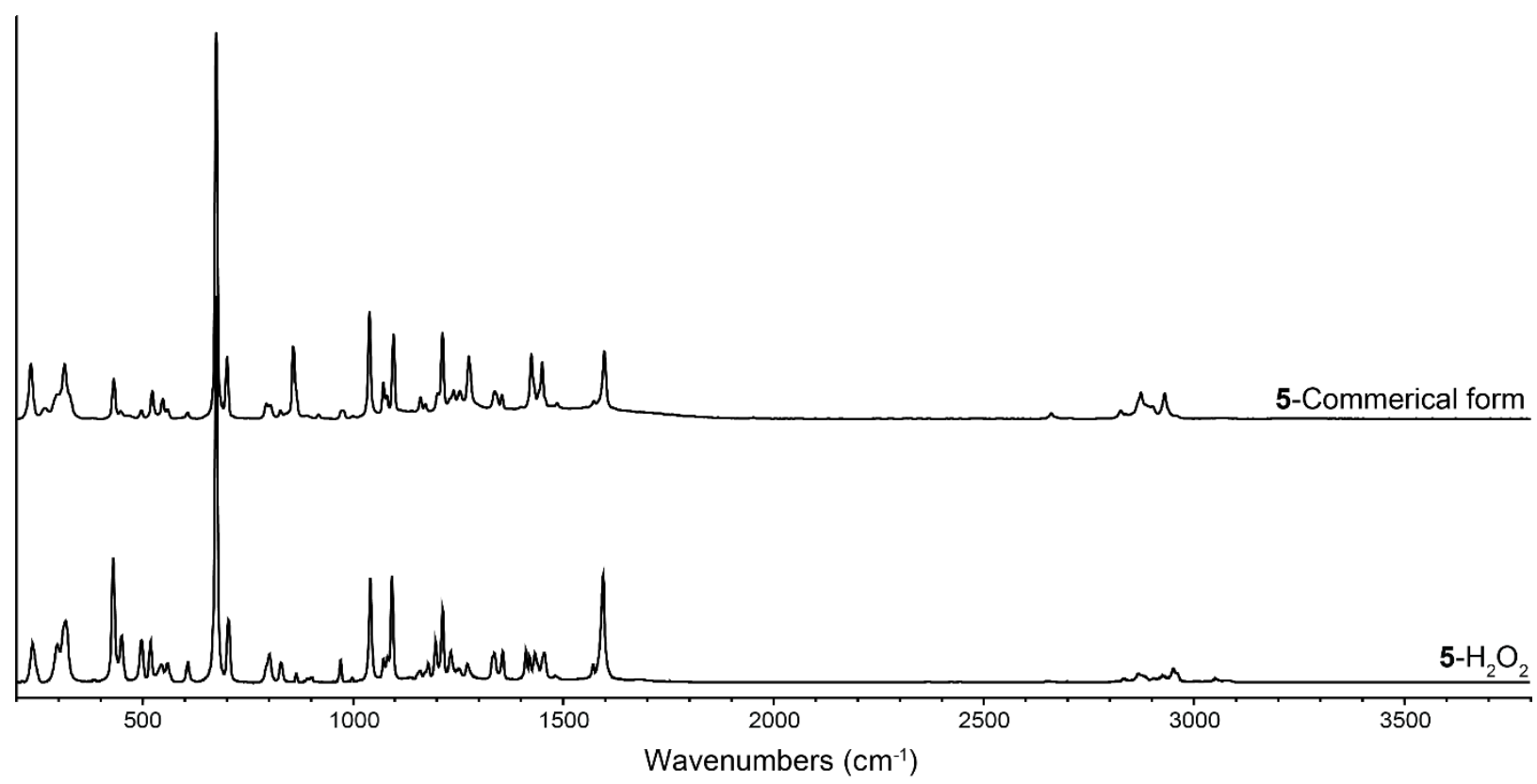


Figure S9. Full Range $\left(200-3800 \mathrm{~cm}^{-1}\right)$. Raman spectra of the commercial form (top) and peroxosolvate (bottom) of 5 .

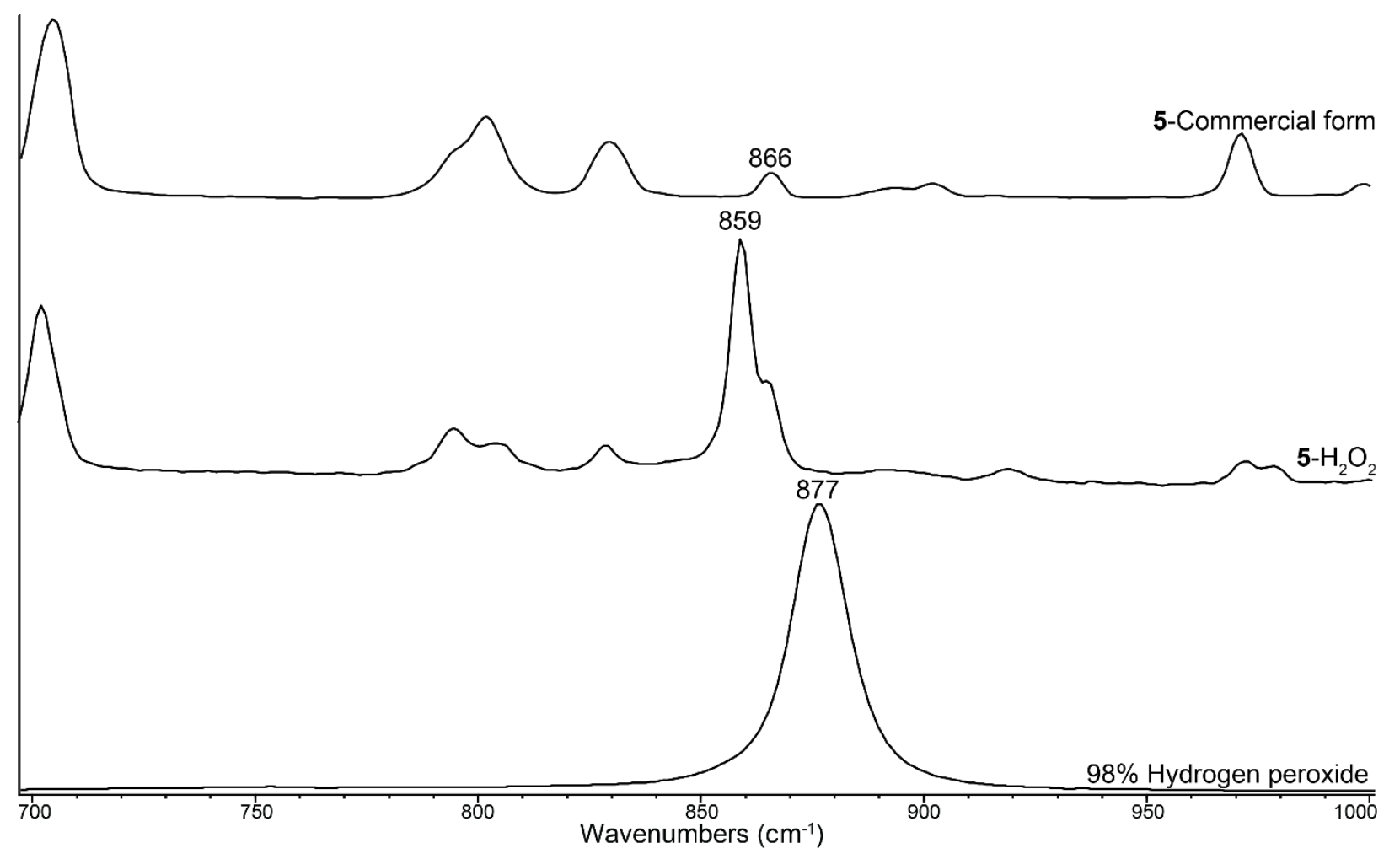

Figure S10. Zoomed in ( $\left.700-1000 \mathrm{~cm}^{-1}\right)$. Raman spectra of the commercial form of 5 (top), the peroxosolvate of $\mathbf{5}$ (middle), and $98 \%$ hydrogen peroxide (bottom) in the region where the hydrogen peroxide O-O stretch can be observed. 


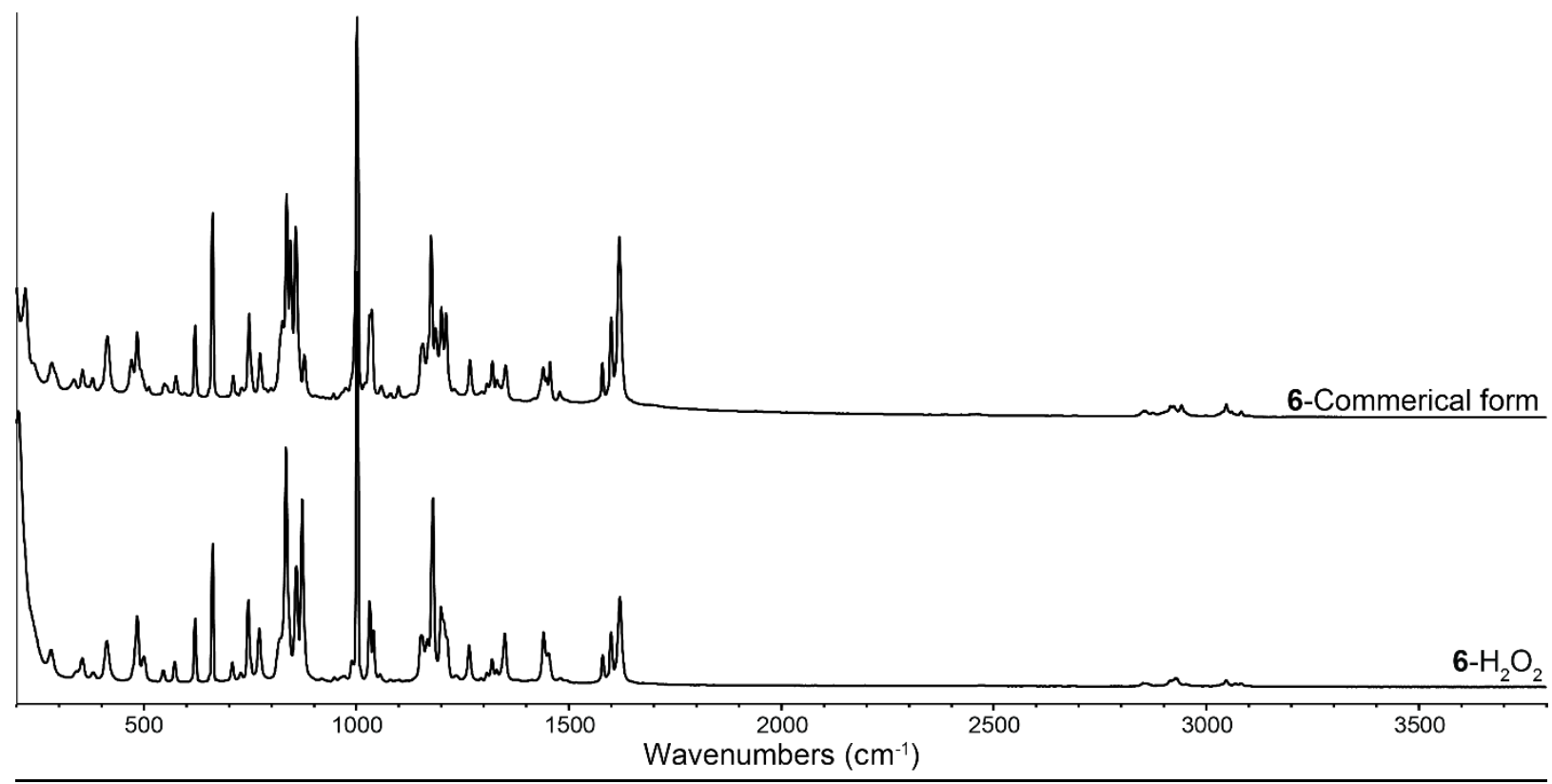

Figure S11. Full Range $\left(200-3800 \mathrm{~cm}^{-1}\right)$. Raman spectra of the commercial form (top) and peroxosolvate (bottom) of 6.

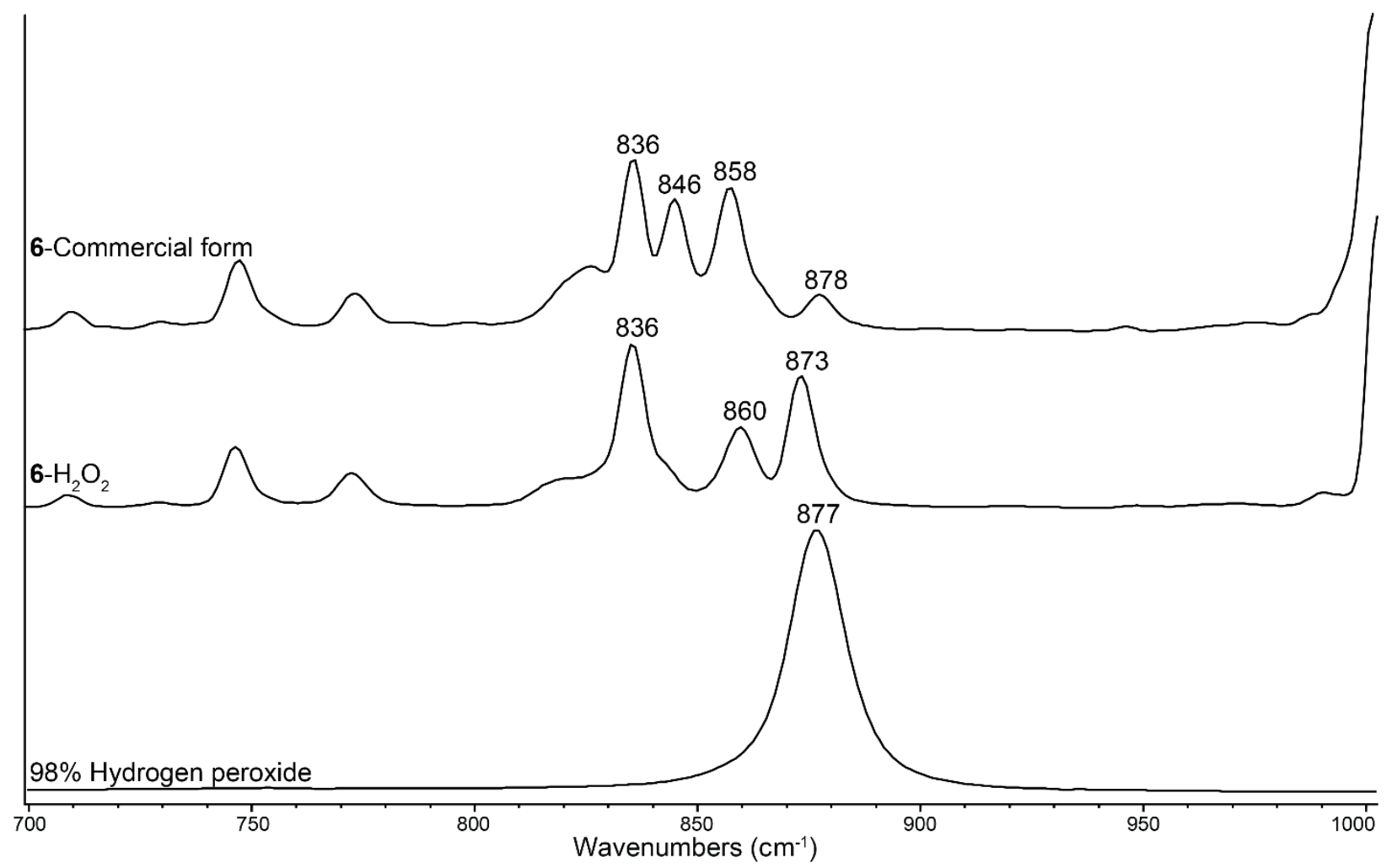

Figure S12.* Zoomed in ( $\left.700-1000 \mathrm{~cm}^{-1}\right)$. Raman spectra of the commercial form of 6 (top), the peroxosolvate of 6 (middle), and 98\% hydrogen peroxide (bottom) in the region where the hydrogen peroxide O-O stretch can be observed. 


\section{S4 Crystallographic Data}

Table S3-S4. Crystallographic data for the peroxosolvates and previously published hydrates of 1-6.

\begin{tabular}{|c|c|c|c|c|c|c|c|}
\hline & $1-\mathrm{H}_{2} \mathrm{O}_{2}$ & $1-\mathrm{H}_{2} \mathrm{O}^{2}$ & $2-\mathrm{H}_{2} \mathrm{O}_{2}$ & 2- $\mathrm{H}_{2} \mathrm{O}^{3}$ & $3-\mathrm{H}_{2} \mathrm{O}_{2}$ & $3-\mathrm{H}_{2} \mathrm{O}^{4}$ & $3-\mathrm{H}_{2} \mathrm{O}^{5}$ \\
\hline Refcode (for hydrates) & -- & EYUBUX & -- & ACOHAC & -- & SOKGAA & XIKPUF \\
\hline $\begin{array}{l}\text { Stoichiometry } \\
\text { Compound:Solvent }\end{array}$ & $1: 1$ & $1: 2$ & $2: 1$ & $1: 1$ & $2: 2$ & $1: 1$ & $3: 1$ \\
\hline Space group & $12 / \mathrm{A}$ & $P 2_{1} / n$ & Pbca & $C 2 / c$ & $112 / a 1$ & $P 2_{1} / n$ & Pbca \\
\hline a $(\AA ̊)$ & $14.5620(3)$ & $8.7709(1)$ & $8.52345(1)$ & $14.174(2)$ & $12.59350(1)$ & $8.091(2)$ & $18.0035(2)$ \\
\hline $\mathrm{b}(\AA ̊)$ & $8.2332(2)$ & $6.9476(9)$ & $13.38705(2)$ & $8.3706(2)$ & $13.0746(2)$ & $6.768(2)$ & $31.8369(2)$ \\
\hline$c(\AA)$ & $14.6932(3)$ & $14.5290(2)$ & $25.3439(3)$ & $13.877(2)$ & $26.7307(3)$ & $18.370(6)$ & $10.2555(1)$ \\
\hline$\alpha(\mathrm{deg})$ & 90 & 90 & 90 & 90 & 90 & 90 & 90 \\
\hline$\beta$ (deg) & $113.325(2)$ & $90.966(12)$ & 90 & $108.469(13)$ & $101.577(1)$ & $91.72(3)$ & 90 \\
\hline$\nu$ (deg) & 90 & 90 & 90 & 90 & 90 & 90 & 90 \\
\hline Volume $\left(A^{3}\right)$ & $1617.63(7)$ & $885.2(2)$ & $2891.84(6)$ & $1543.0(5)$ & $4311.80(9)$ & 1005.49 & $5878.2(9)$ \\
\hline$\rho_{\text {calc }}\left(\mathrm{g} \mathrm{cm}^{-3}\right)$ & 1.291 & 1.194 & 1.288 & 1.215 & 1.570 & 1.587 & 1.547 \\
\hline $2 \theta \max$ & 66.53 & -- & 66.60 & -- & 66.60 & & \\
\hline Temperature (K) & $299(6)$ & $296(2)$ & $100(1)$ & $193(2)$ & $301(1)$ & 153 & $250(1)$ \\
\hline Reflections Collected & 6204 & -- & 9054 & -- & 11324 & -- & -- \\
\hline Unique Reflections & 1428 & -- & 2546 & -- & 3804 & -- & -- \\
\hline Included Reflections & 1331 & -- & 2342 & -- & 3515 & -- & -- \\
\hline Parameters & 137 & -- & 194 & -- & 360 & -- & -- \\
\hline $\mathrm{R}_{1} / \mathrm{wR}_{2}$ & $3.87 / 10.55$ & $4.67 / 14.05$ & $3.44 / 8.85$ & $4.70 / 12.93$ & $4.30 / 12.84$ & 4.10/-- & 2.43/-- \\
\hline GOF & 1.085 & 1.016 & 1.129 & 1.034 & 0.848 & -- & 1.947 \\
\hline
\end{tabular}




\begin{tabular}{|c|c|c|c|c|c|c|c|}
\hline & $4-\mathrm{H}_{2} \mathrm{O}_{2}$ & $4-\mathrm{H}_{2} \mathrm{O}^{6}$ & $4-\mathrm{H}^{2} \mathrm{O}^{6}$ & $5-\mathrm{H}_{2} \mathrm{O}_{2}$ & $5-\mathrm{H}_{2} \mathrm{O}^{7}$ & $6-\mathrm{H}_{2} \mathrm{O}_{2}$ & $6-\mathrm{H}_{2} \mathrm{O}^{8}$ \\
\hline Refcode (for hydrates) & -- & FADXUG & FADYAN & -- & KUSYAZ & -- & QONLIP \\
\hline $\begin{array}{l}\text { Stoichiometry } \\
\text { Compound:Solvent }\end{array}$ & $1: 2$ & $2: 1$ & $1: 2$ & $2: 1$ & $2: 1$ & $1: 1$ & $1: 1$ \\
\hline Space group & $\mid 12 / a 1$ & Pbca & $P 21 / c$ & $I 12 / a 1$ & Pbca & Pbca & Pcab \\
\hline a $(\AA ̊)$ & $15.7635(6)$ & $12.7754(2)$ & $6.772(5)$ & $6.9397(2)$ & $14.725(4)$ & $11.5665(2)$ & $9.3420(1)$ \\
\hline$b(\AA)$ & $6.91099(2)$ & $9.7518(8)$ & $15.829(5)$ & $7.5687(2)$ & $14.464(4)$ & $9.4886(2)$ & $11.7920(2)$ \\
\hline$c(\AA ̊)$ & $19.9934(6)$ & $14.6743(2)$ & $9.608(2)$ & $8.3307(3)$ & $15.474(3)$ & $22.7892(4)$ & $21.8200(4)$ \\
\hline$\alpha(\operatorname{deg})$ & 90 & 90 & 90 & $91.738(3)$ & 90 & 90 & 90 \\
\hline$\beta$ (deg) & $113.155(4)$ & $112.81(2)$ & $106.39(4)$ & $101.247(3)$ & 90 & 90 & 90 \\
\hline$\gamma$ (deg) & 90 & 90 & 90 & $110.298(3)$ & 90 & 90 & 90 \\
\hline Volume $\left(A^{3}\right)$ & $2002.66(1)$ & $1685.2(3)$ & $988.0(8)$ & $400.22(2)$ & $3295.7(1)$ & $2501.11(8)$ & $2403.71(7)$ \\
\hline$\rho_{\text {calc }}\left(\mathrm{g} \mathrm{cm}^{-3}\right)$ & 1.394 & 1.326 & 1.312 & 1.371 & 1.275 & 1.303 & 1.278 \\
\hline $2 \theta \max$ & 66.57 & & & 66.52 & & 75.87 & -- \\
\hline Temperature (K) & $100(1)$ & 250 & $293(2)$ & $100(1)$ & $293(2)$ & $100(1)$ & $150(2)$ \\
\hline Reflections Collected & 3445 & & & 5081 & & 5481 & -- \\
\hline Unique Reflections & 1774 & & & 1412 & & 2607 & \\
\hline Used Reflections & 1562 & & & 1311 & & 2191 & \\
\hline Parameters & 150 & & & 114 & & 171 & \\
\hline$R_{1} / w R_{2}$ & $3.57 / 10.47$ & $2.16 /--$ & $6.20 / 21.17$ & $3.50 / 9.86$ & $5.12 / 20.48$ & $3.99 / 11.20$ & $3.95 / 9.83$ \\
\hline GOF & 1.061 & 1.734 & 1.021 & 1.096 & 1.388 & 1.070 & 1.042 \\
\hline
\end{tabular}




\section{S5. ORTEP Diagrams}

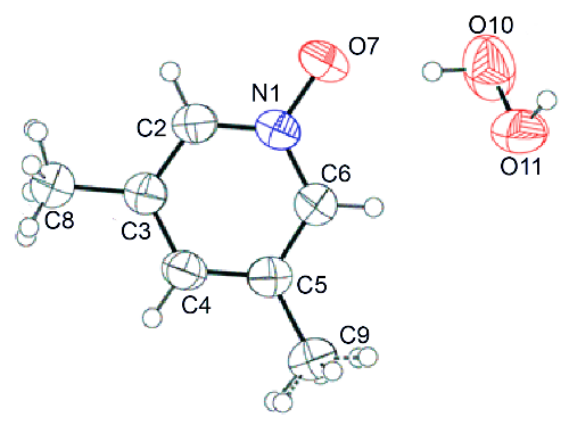

Figure S13. ORTEP diagram for $1-\mathrm{H}_{2} \mathrm{O}_{2}$ collected at $299(6) \mathrm{K}$ with thermal ellipsoids of $50 \%$ probability

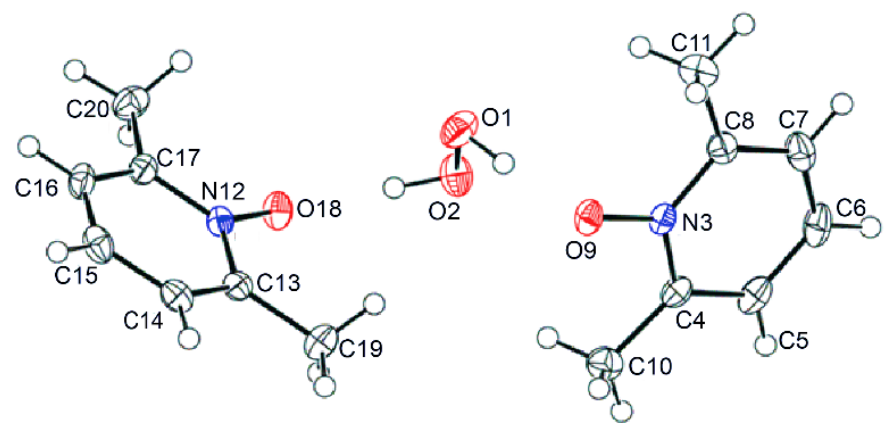

Figure S14 ORTEP diagram for $\mathbf{2}-\mathrm{H}_{2} \mathrm{O}_{2}$ collected at $100(1) \mathrm{K}$ with thermal ellipsoids of $50 \%$ probability

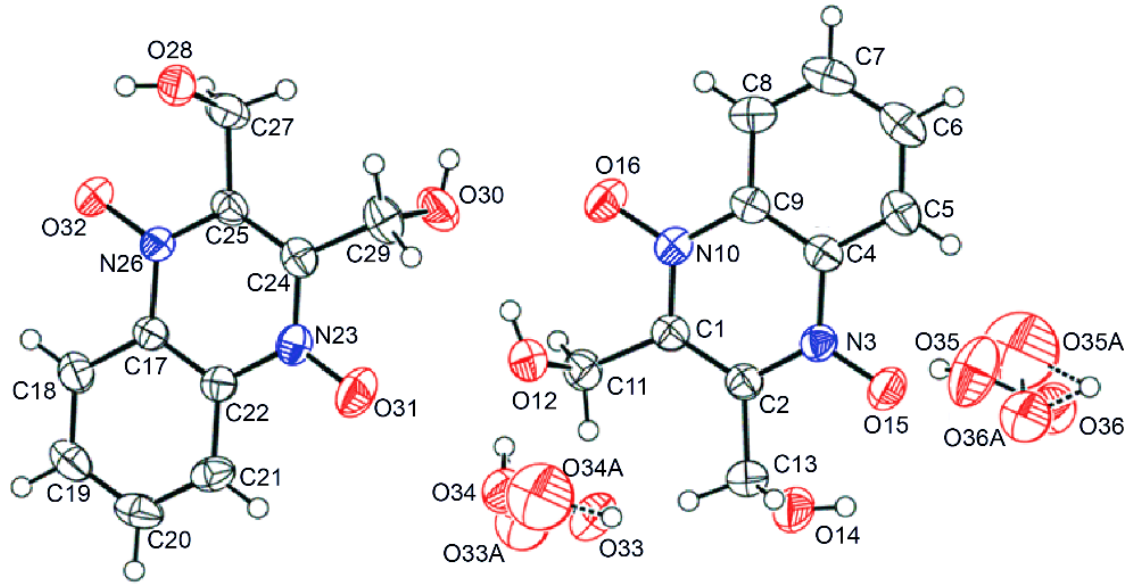

Figure S15. ORTEP diagram for $\mathbf{3}-\mathrm{H}_{2} \mathrm{O}_{2}$ collected at $301(1) \mathrm{K}$ with thermal ellipsoids of $50 \%$ probability 


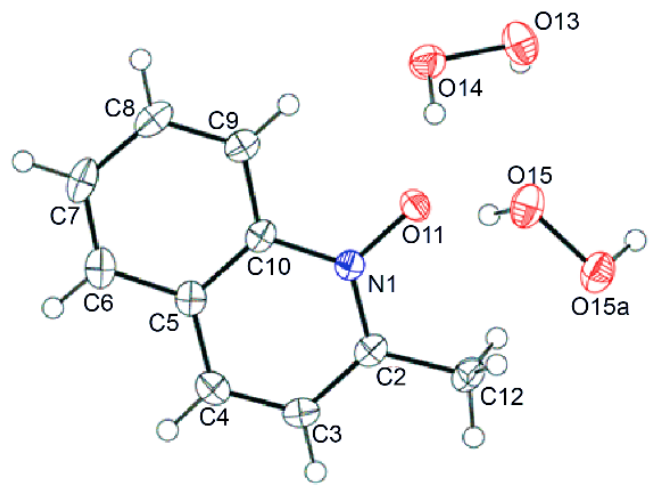

Figure S16. ORTEP diagram for $4-\mathrm{H}_{2} \mathrm{O}_{2}$ collected at $100(1) \mathrm{K}$ with thermal ellipsoids of $50 \%$ probability

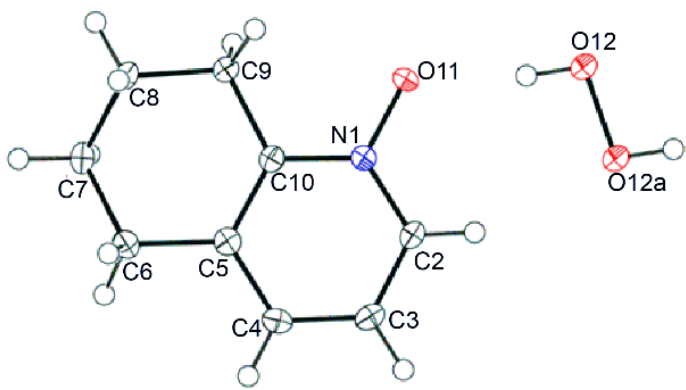

Figure S17. ORTEP diagram for $5-\mathrm{H}_{2} \mathrm{O}_{2}$ collected at $100(1) \mathrm{K}$ with thermal ellipsoids of $50 \%$ probability

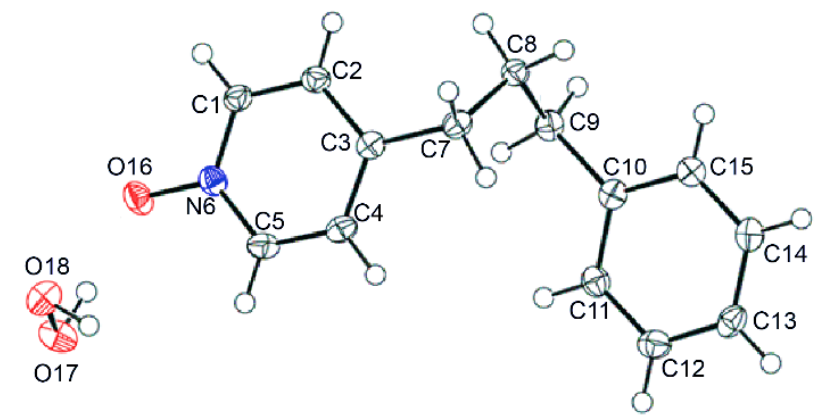

Figure S18. ORTEP diagram for $\mathbf{6}-\mathrm{H}_{2} \mathrm{O}_{2}$ collected at 100 (1) $\mathrm{K}$ with thermal ellipsoids of $50 \%$ probability 


\section{S6. Crystal Morphology}

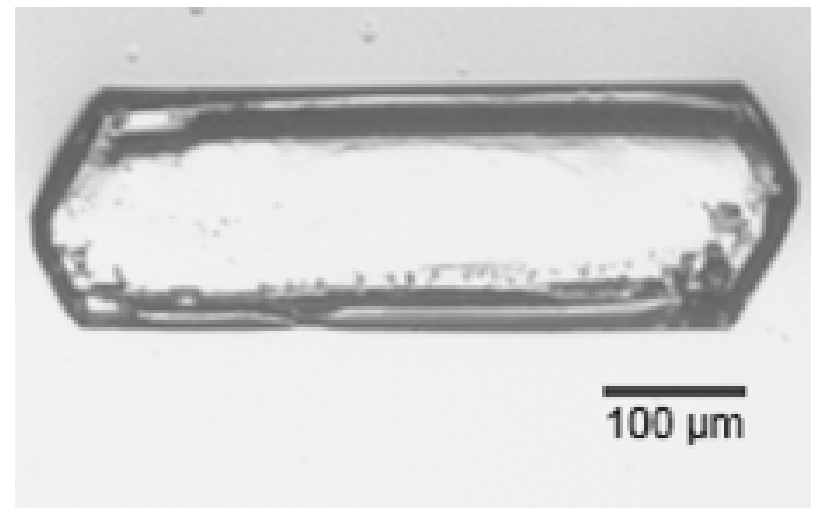

Figure S19. Characteristic crystals of $1-\mathrm{H}_{2} \mathrm{O}_{2}$ grown from a slurry in $50 / 50$ by volume ethyl acetate/98 hydrogen peroxide.

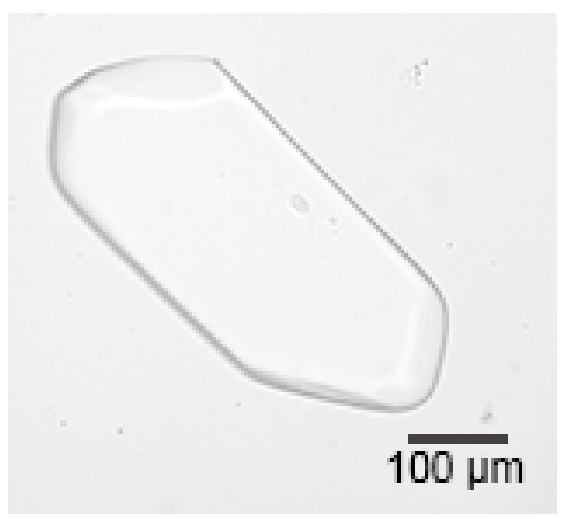

Figure 20. Characteristic crystals of $\mathbf{2}-\mathrm{H}_{2} \mathrm{O}_{2}$ grown when $98 \%$ hydrogen peroxide was added to $\mathbf{2}$.

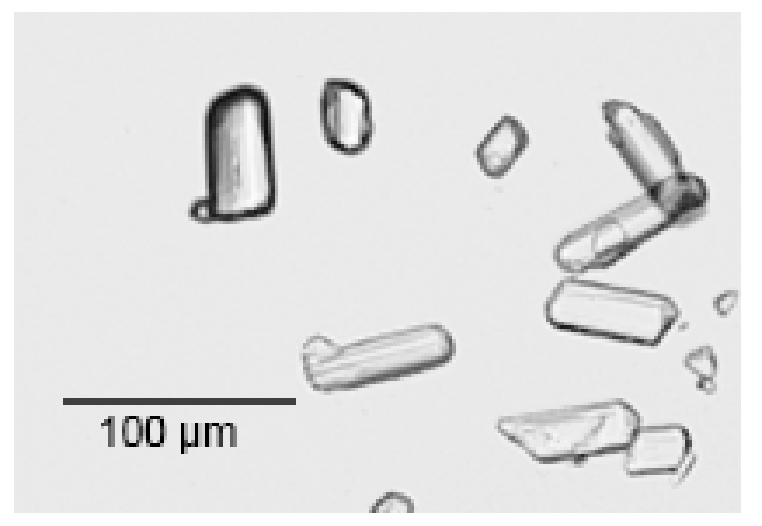

Figure 21. Characteristic crystals of $3-\mathrm{H}_{2} \mathrm{O}_{2}$ grown from a slurry of $98 \%$ hydrogen peroxide. 


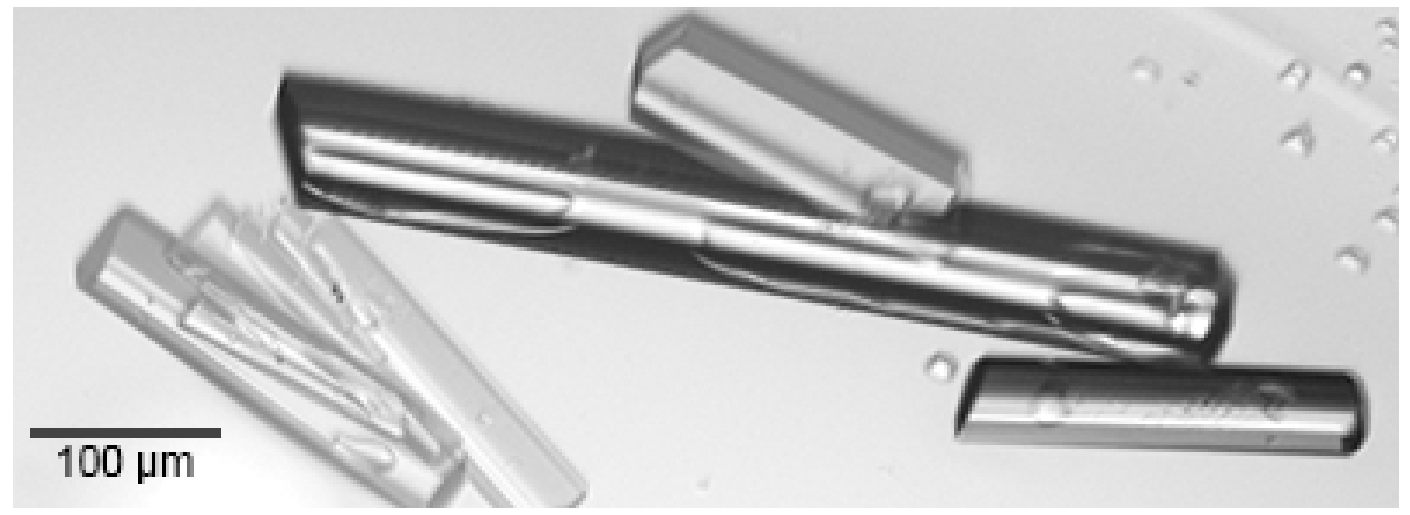

Figure 22. Characteristic crystals of $4-\mathrm{H}_{2} \mathrm{O}_{2}$ grown from a slurry of $50 / 50$ by volume acetonitrile/98\% hydrogen peroxide.

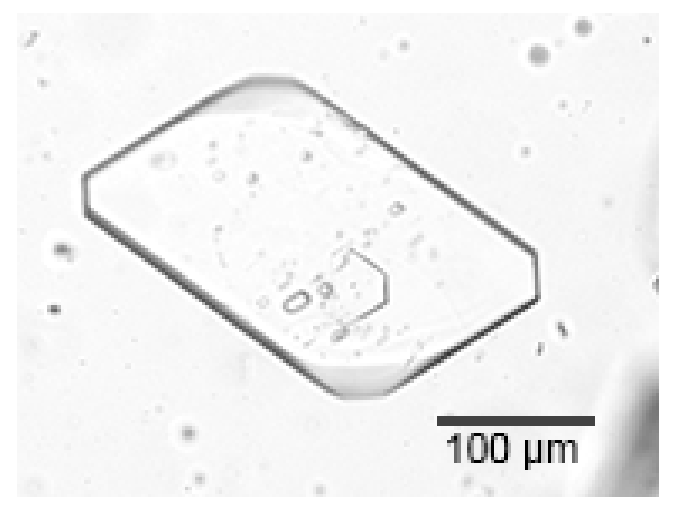

Figure 23. Characteristic crystals of $5-\mathrm{H}_{2} \mathrm{O}_{2}$ grown from a slurry of $50 / 50$ by volume dichloromethane/98\% hydrogen peroxide.

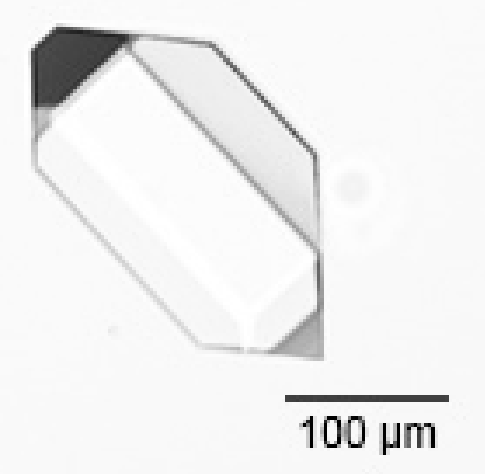

Figure 24. Characteristic crystals of $6-\mathrm{H}_{2} \mathrm{O}_{2}$ grown from a slurry of $50 / 50$ by volume acetonitrile/98\% hydrogen peroxide. 


\section{References}

1 C. R. Groom, I. J. Bruno, M. P. Lightfoot and S. C. Ward, Acta Crystallogr. Sect. B Struct. Sci. Cryst. Eng. Mater., 2016, 72, 171-179.

2 R. Merino García, F. J. Ríos-Merino, S. Bernès and Y. Reyes-Ortega, Acta Crystallogr. Sect. E Crystallogr. Commun., 2016, 72, 1687-1690.

3 J. G. Planas, G. G. Mohamed, R. Sillanpää, R. Kivekäs, F. Teixidor and C. Viñas, J. Mol. Struct., 2006, 787, 121126.

4 G. G. Dvoryantseva, S. V. Lindeman, M. S. Aleksanyan, Yu. T. Struchkov, K. P. Teten'chuk, L. S. Khabarova and A. S. Elina, Pharm. Chem. J., 1990, 24, 672-677.

5 T. I. Shabatina, O. I. Vernaya, V. P. Shabatin, I. V. Evseeva, M. Y. Melnikov, A. N. Fitch and V. V. Chernyshev, Crystals, 2018, 8, 298 (1-15).

6 V. P. Andreev, D. O. Zaitsev, Y. A. Velikodny and V. V. Chernyshev, Eur. Chem. Bull., 2014, 3, 452-456.

7 Z. Karczmarzyk, T. M. Lipińska, W. Wysocki, Z. Urbańczyk-Lipkowska and P. Kalicki, Acta Crystallogr. Sect. E Struct. Rep. Online, 2010, 66, o806-0807.

8 I. Richter, M. R. Warren, J. Minari, S. A. Elfeky, W. Chen, M. F. Mahon, P. R. Raithby, T. D. James, K. Sakurai, S. J. Teat, S. D. Bull and J. S. Fossey, Chem. - Asian J., 2009, 4, 194-198.

9 O. V. Dolomanov, L. J. Bourhis, R. J. Gildea, J. A. K. Howard and H. Puschmann, J. Appl. Crystallogr., 2009, 42, 339-341.

10 G. M. Sheldrick, Acta Crystallogr Sect Found Adv, 2015, 71, 3-8.

11 G. M. Sheldrick, Acta Crystallogr Sect C Struct Chem, 2015, 71, 3-8. 